\title{
Natural Disasters and Local Development in Northeast Brazil: The Case of Droughts and Floods in Ceará State*
}

\author{
Victor Hugo de Oliveira ${ }^{\dagger} \quad$ João Mário S. de França Francisco Mário V. Martins $^{\S}$
}

December 17, 2019

\begin{abstract}
Using data from the Damage Assessment Reports from the Civil Defence, the current study investigates the relationship between the damages caused by natural disasters and local development at the municipality level in Ceará state, Brazil. The results show that a better urban and water supply infrastructure, a lower population density, and a higher proportion of own revenues relative to total revenues are associated with smaller disaster damages. However, economic development in terms of GDP per capita exhibits a convex relationship with the impact of natural disasters across municipalities, reflecting the potential decreasing returns of preventive investments due to the highly hazardous environment that involves municipalities.
\end{abstract}

Keywords: Natural Disasters, Local Development, Ceará, Brazil.

JEL: Q54, R11, R58.

\footnotetext{
* Francisco Mário V. Martins would like to thank the Fundação Cearense de Apoio ao Desenvolvimento Científico e Tecnológico (FUNCAP) for financial support. The authors thank the valuable contributions of the anonymous referees. All remaining errors are our responsibility.

${ }^{\dagger}$ Public Policy Analyst, Institute of Research and Economic Strategy of Ceará.

Corresponding author: vhosilva@gmail.com / victor.hugo@ipece.ce.gov.br; Phone: +55 85987871979

* Associate Professor, Graduate Program in Economics, Federal University of Ceará. Head of the Department of Social Studies, Institute of Research and Economic Strategy of Ceará.

$\S$ Graduate student, Graduate Program in Economics, Federal University of Ceará.
} 


\section{Introduction}

The increasing incidence of climate-related and geophysical disasters has caused devastating impacts on social and economic development worldwide, generating direct costs that amount to US\$ 2,908 billion in the last two decades (1998-2017). While the majority of fatalities were due to geophysical events (mostly earthquakes and tsunamis), $77 \%$ of all direct costs were caused by climate-related disasters (UNISRD, 2017).

In Brazil, a developing country highly exposed to extreme weather events, there were 38,996 records of natural disasters, with a predominance of droughts $(51.3 \%)$ and floods (32.7\%), between 1991 and 2012. During this period, on average, 6 million people were affected by natural disasters (CEPED, 2013). The total cost of damages amounts to R $\$ 137$ billion (US\$ 119 billion PPP) between 1995 and 2014 (CEPED, 2016). ${ }^{5}$ In addition, the negative prognoses on climate change tends to further accentuate these impacts in Brazil (IPCC, 2012; PBMC, 2015), which demands investigations about how economic development can contribute to mitigating the impacts of environmental shocks on population well-being.

The occurrence of natural disasters is always preceded by the existence of specific physical and social conditions that are generally referred to as disaster risk (Wisner et al., 2004, UNISDR, 2009, 2011). In this sense, the usual formulation of disaster risk is associated with the notions of vulnerability, exposure and the natural process itself, accompanied by possible adverse effects in the future (IPCC, 2012).

The specialized literature on disaster risk analysis has provided evidence on the influence of such dimensions on the risk of environmental disasters across countries. In China, for instance, population exposure is found to be an important risk factor, and the high socioeconomic vulnerability magnifies the levels of disaster risk (Zhou et al., 2015). In India,

\footnotetext{
${ }^{5}$ Real value of 2014 based on the GDP deflator (CEPED, 2016).
} 
flood risk is rooted in not only extreme hydrometeorological events but also important social factors, such as population growth, land-use change, settlement patterns, and the distribution of poverty, that greatly aggravate the risk of flooding (Okuyama and Sahin, 2009). In Brazil, the risk of flooding is associated with not only a low level of socioeconomic status of the exposed population but also the poor governance that is widespread across all regions of the country (Rasch, 2016).

A particular focus of the literature is to understand how economic development can reduce the risk of environmental shocks. Some empirical studies have demonstrated a strong negative relationship between economic development and the risk of death from natural disasters (UNDP, 2004; Kahn, 2005; Toya and Skidmore 2007; Yonson et al. 2017), supporting the hypothesis that wealthy countries are less likely to suffer impacts from natural disasters (Kellenberg and Mobarak, 2008, Cavallo \& Noy, 2011). In this context, Kellenberg and Mobarak (2008) argue that behavioural changes at the micro level in response to increasing income (such as location choice and extent of costly abatement activity) may lead to a nonlinear relationship between aggregate incomes and disaster damages, where the risks increase with income before they decrease. However, Raschky (2008) finds a U-shaped relationship between economic development and economic disaster losses, suggesting that economic development is a good protection against natural hazards, but with a diminishing rate.

Schumacher and Strobl (2011) contribute to such discussion by showing theoretically and empirically that the sort of nonlinearity between economic losses caused by natural disasters and income level depends on how exposed the countries are to environmental shocks. Regions that face a high (low) hazard of disasters are likely to first experience decreasing (increasing) losses and then increasing (decreasing) losses with increasing economic development. Particularly, this prediction has important implications for public policy; regions that are prone to environmental shocks may experience a large impact of natural disasters as 
their incomes rise above the turning point. A potential solution is the integration of disaster risk reduction (DRR) measures into the development plans and policies of such regions, which can help them to attain a sustainable development path (Hay and Mimura, 2010; Hallegatte et al., 2017).

The objective of this investigation is to contribute to this literature by providing empirical evidence of a relationship between local development and the impact of natural disasters in Ceará state, Brazil, by using data from the Damage Assessment Reports from the Civil Defence (Relatório de Avaliação de Danos - AVADAN). Ceará exhibits the $4^{\text {th }}$ largest number of records and the $5^{\text {th }}$ largest amount of losses caused by natural disasters between 1994 and 2014 among Brazilian federal unities (CEPED, 2016). Moreover, almost all of its territory $(87 \%)$ and more than half of its population $(56 \%)$ are within the great semi-arid region of Brazil. ${ }^{6}$ Taking into account the occurrence of extreme weather events and the level exposure of the municipalities, we aim to provide evidence that development can mitigate the impact of natural disasters at the local level.

Furthermore, Ceará is located in the poorest region of Brazil, the Northeast Region. It has the $8^{\text {th }}$ largest population out of 27 federal unities (i.e., 8.5 million, which is slightly larger than the population of Austria), but only the fifth lowest per capita GDP (US\$ 6,652 PPP) and economically comparable to Guatemala (US\$ 6,578 PPP). The climate conditions, the exposure of the population and, especially, the socioeconomic vulnerability to environmental shocks are similar to other federal unities of the Northeast Region (Hummel et al., 2016); however, Ceará state shows a well-structured preparedness policy to droughts in comparison to other states of the region (Gutiérrez et al., 2014).

It is important to emphasize that the current study differs from De Oliveira (2019), although they are directly related. De Oliveira (2019) shows evidence that damages from natural

\footnotetext{
${ }^{6}$ The Brazilian semi-arid region is characterized by annual precipitation below $800 \mathrm{~mm}$, a dryness index of 0.5 or below, and a risk of drought of at least $60 \%$.
} 
disasters can negatively affect the economic development of municipalities by lowering their economic growth rates in the short run. The author assumes that the damages from natural disasters are endogenously determined once the factors that underlie the economic growth are also important determinants of the level of the vulnerability of the municipalities to environmental shocks (e.g., urban and water supply infrastructure and public spending). However, De Oliveira (2019) does not explicitly show evidence on how the magnitude of natural disasters can be affected by the level of development of municipalities. The current study provides evidence that the level of the development of municipalities matters to determine how large the damages caused by natural disasters are in Ceará state.

The results show that municipalities with better access to urban infrastructure and water supply, as well as better tax collection and lower public spending, exhibit a lower impact of natural disasters. However, evidence also suggests that economic development in terms of GDP per capita exhibits a convex relationship with the impact of natural disasters, corroborating Schumacher and Strobl (2011). This nonlinear relationship is basically driven by the relationship between the impact of droughts and income, while the relationship between the impact of floods and income is linear and negative.

Our study contributes to the literature in two aspects. First, we show that the nonlinear relationship between the impact of natural disasters and income can be observed at the subnational level, when the majority of studies provide evidence at the country level (Kahn, 2005; Toya and Skidmore, 2007; Peduzzi et al., 2009; Schumacher and Strobl, 2011). Yonson et al. (2017), for instance, investigate the relationship between the impact of tropical cycloneinduced and socio-economic vulnerabilities at the provincial level for the Philippines and find a negative relationship between fatalities and income. Second, this nonlinear relationship depends on the type of natural disasters, because regions may differ from each other in terms of the type of environmental shock they are more exposed to. In the literature, the relationship 
is usually tested using the aggregated measure of the impact of all natural disasters (Raschky, 2008; Schumacher and Strobl, 2011).

The remainder of this study is structured as follows: Section 2 presents an empirical model; Section 3 describes the data sources; and Section 4 analyses the results. Finally, Section 5 concludes the study.

\section{Empirical Model}

Disaster risk is the possibility of adverse effects in the future due to a disaster occurrence, being a combination of physical hazards, exposure (or exposed elements) and vulnerabilities (IPCC, 2012). ${ }^{7}$ It can be expressed by the following formula (UNDRO, 1980, Cardona, 2011):

$$
\text { Risk }=\text { Hazard } \times \text { Exposure } \times \text { Vulnerability }
$$

where Hazard is the natural or human-induced physical event that produces human and/or material losses. Exposure refers to the inventory of elements (including people) in an area in which hazard events may occur. Vulnerability is defined as the propensity or predisposition to be adversely affected.

The empirical strategy of this analysis relies on a variation of the generalized multiplicative model of Peduzzi et al. (2009) relative to equation (1). We model the risk as

$$
\operatorname{Risk}=C E^{\delta}\left(V_{1}^{\beta_{1}} V_{2}^{\beta_{2}} \cdots V_{K}^{\beta_{K}}\right) \exp ^{\theta H}
$$

where $C$ is a multiplicative constant, $H$ is the measure of hazard, $E$ is the measure of exposure, and $V_{K}$ is the $\mathrm{K}^{\text {th }}$ measure of vulnerability. We are assuming that the risk of natural disasters increases exponentially with hazard. Moreover, Peduzzi et al. (2009) assume that if there is no

\footnotetext{
${ }^{7}$ The Intergovernmental Panel on Climate Change (IPCC, 2012) defines disaster risk as "the likelihood over a specified time period of severe alterations in the normal functioning of a community or a society due to hazardous physical events interacting with vulnerable social conditions, leading to widespread adverse human, material, economic, or environmental effects that require immediate emergency response to satisfy critical human needs and that may require external support for recovery".
} 
hazard (e.g., no occurrence of cyclones or droughts), the risk of natural disasters is null. In equation (2), we relax this assumption since the measure of hazard is based on the annual precipitation of municipalities.

Taking the natural log of equation (2) allows us to measure elasticities regarding the impact of exposure $(\delta)$ and vulnerability $\left(\beta_{1}, \beta_{2}, \ldots, \beta_{k}\right)$ on the measure of the natural disaster. A semi-elasticity is obtained regarding the impact of the hazard $(\theta)$ on the measure of the natural disaster. That is,

$$
\ln N D=\alpha+\theta H+\delta \ln E+\sum_{k=1}^{K} \beta_{k} \ln V_{k}
$$

where $\alpha=\ln C$. The dependent variable is $N D$; that is, the measure of the impact of natural disasters, expressed in terms of the proportion of the affected population relative to the population size $(A P)$ and disaster losses per capita $(D L)$.

Using a panel data framework to estimate the semi-elasticity and elasticities, we reformulate equation (3) as follows:

$$
\begin{aligned}
& \ln N D_{i t}^{*}=\alpha+\theta H_{i t}+\delta \ln E_{i t}+\sum_{i=1}^{k} \beta_{i} \ln V_{k, i t-1}+\varepsilon_{i t} \\
& \ln N D_{i t}=\left\{\begin{array}{c}
\ln N D_{i t}^{*} \text { if } \ln N D_{i t}^{*}>0 \\
0, \text { otherwise }
\end{array}\right.
\end{aligned}
$$

where $i=1, \ldots, 184$ and $t=2002, \ldots, 2011$. Lagged vulnerability controls are included in the model to prevent reversal causation with natural disaster impact (Schumacher and Strobl, 2011).

An important aspect regarding equation (4) is that the dependent variable is leftcensored, once a disaster is recorded by the Civil Defence in Brazil, only after notification of the existence of affected people and/or economic losses caused by the environmental shock (MIN, 2007). In this case, the panel Tobit model is used to estimate the parameters of equation (4). Thus, the error term $\varepsilon_{i t}$ in (4) has two components: $v_{i} \sim N I D\left(0, \sigma_{v}^{2}\right)$ is the time-invariant 
individual random effect, and $\eta_{i t} \sim N I D\left(0, \sigma_{\eta}^{2}\right)$ is the time-varying idiosyncratic random error, which are assumed to be independent of each other. ${ }^{8}$

\section{Data}

\subsection{Study area}

Ceará is one of the nine states in Northeast Brazil with a total area of approximately 148,886 $\mathrm{km}^{2}$ (see Figure 1). The predominant climate is the hot tropical semi-arid climate, which promotes the occurrence of drought episodes that are often associated with large-scale climate phenomena, such as El Niño and La Niña, or with an intense meridional sea surface temperature (SST) gradient over the tropical Atlantic (Marengo et al., 2017).

\section{[INSERT FIGURE 1 ABOUT HERE]}

On average, the population size of municipalities is 46,000 inhabitants. The capital of the state, Fortaleza, has 2.5 million inhabitants according to the 2010 Demographic Census. ${ }^{9}$ According to the 2013 Atlas of Human Development in Brazil, the average Human Development Index across municipalities was approximately 0.62 in 2010, and only 4 out of 184 municipalities exhibited values above 0.7 . On average, the poverty rate is approximately $68 \%$ of the population of the municipalities and the life expectancy is near 71 years. ${ }^{10}$ The average fertility rate is approximately 2.3 children per woman and the infant mortality rate is almost 25 per 1,000 live births. ${ }^{11}$

\footnotetext{
${ }^{8}$ We do not model fixed effects at the municipality level because estimators will be biased due to the incidental parameter problem (Greene, 2004).

9 For further details, access the link: https://sidra.ibge.gov.br/pesquisa/censo-demografico/demografico2010/inicial.

${ }^{10}$ The poverty rate is the proportion of the population of the municipality with per capita household incomes lower than half the minimum wage per capita ( $\$$ \$ 255).

${ }^{11}$ All of these socioeconomic indicators at the municipality level of the 2013 Atlas of Human Development in Brazil can be found at the following link: http://www.atlasbrasil.org.br/2013/en/.
} 
In terms of economic activity, the service/commerce sector is responsible for $65 \%$ of the total GDP between 2004 and 2011. Manufacturing and agriculture make up approximately $14 \%$ and $16 \%$, respectively, of the total output of the municipalities. While the municipalities of the metropolitan region concentrate most of the value added of services/commerce and manufacturing, $81 \%$ of the value added by agriculture is generated by the municipalities of the semi-arid region (De Oliveira, 2019).

\subsection{Exposure of municipalities to climate hazards}

Given that the semi-arid region lies across almost all of Ceará's territory, droughts are expected to be the most frequent climate event across municipalities. Figure 2 displays the box-plot of the distribution of municipalities regarding the deviation of annual precipitation relative to their historical means of precipitation in the previous 30 years. ${ }^{12}$ The sample mean equals $-0.52 \%$ with a standard deviation of 34.43 . Negative deviations are observed for more than $75 \%$ of municipalities in 2005, 2007 and 2010. The period between 2004 and 2006 was a prolonged drought period for at least $50 \%$ of municipalities in Ceará.

\section{[INSERT FIGURE 2 ABOUT HERE]}

However, rainfall seasons in 2004, 2009 and 2011, led to positive deviations in the annual precipitation for more than two-thirds of municipalities. The positive deviation is more than double the historical mean in some municipalities, which would result in disaster due to excessive rainfall. Thus, a hypothesis to be tested in this study is if these extreme deviations of

\footnotetext{
${ }^{12}$ The box-plot (Figure 2) indicates the 75th percentile (the upper hinge), the median value, and the 25 th percentile (the lower hinge) of the average deviation of annual precipitation of municipalities regarding their historical means. It is also possible to identify the (upper and lower) adjacent lines and the outside values (or potential outliers).
} 
the level of precipitation regarding the historical means of the municipalities imply natural disasters, either related to droughts or floods.

Using data from the Damage Assessment Reports of the Civil Defence (Relatório de Avaliação de Danos - AVADAN), De Oliveira (2019) shows that extreme climate events were the main causes of natural disasters in Ceará between 2002 and 2011. Slightly more than twothirds of the disasters $(76.4 \%)$ were caused by droughts, while the other $22.9 \%$ were due to floods. This evidence is also documented by the Atlas Brasileiro de Desastres Naturais 19912012 (CEPED, 2013). Figure 3 shows that almost all municipalities did report damages due to droughts or floods between 2002 and 2011.

\section{[INSERT FIGURE 3 ABOUT HERE]}

On average, approximately $7.2 \%(\mathrm{SD}=11.48)$ of the population of the municipalities was affected by natural disasters, $11.2 \%(\mathrm{SD}=20.63)$ due to droughts and $3.14 \%(\mathrm{SD}=11.06)$ due to floods (see Table 1). Figure 4 displays maps of the distribution of the municipalities according to the percentage of population affected by droughts and floods.

\section{[INSERT FIGURE 4 ABOUT HERE]}

Municipalities with a population affected by droughts may also be affected by floods. This evidence is observed in Figure 5, which shows the spatial distribution of per capita losses due to droughts and floods. De Oliveira (2019) shows that the average value of per capita losses is $\mathrm{R} \$ 127.22(\mathrm{SD}=881.51), \mathrm{R} \$ 67.34(\mathrm{SD}=456.10)$ due to droughts and $\mathrm{R} \$ 58.50(\mathrm{SD}=757.01)$ due to floods. 
[INSERT FIGURE 5 ABOUT HERE]

\subsection{Vulnerability of municipalities to natural disasters}

In this subsection, the objective is to present proxy variables that account for municipality vulnerability to natural disasters. It is important to specifically account for Susceptibility and Lack of Resilience (IPCC, 2012). Measures of Susceptibility include an index of the urban infrastructure of municipalities based on principal components that include schools, health establishments, the fleet of trucks, and the number of firms. All of these variables are normalized by the population size of municipalities to produce an index that varies from 0 to 100. An index of water supply infrastructure is also included as a measure of Susceptibility in the analysis. ${ }^{13}$ De Oliveira (2019) has shown that water supply infrastructure contributes to reducing the impact of natural disasters on the growth rate of the service sector, despite the absence of its mitigating role regarding the agriculture sector. We also include population density as a measure of the predisposition of human beings to natural disasters.

To account for the Lack of Resilience, we include total GDP per capita of the municipalities, expenditure per capita, and tax revenue relative to total revenue. Total GDP per capita is our measure of income and captures the differences in the level of economic development across municipalities. Toya and Skidmore (2007) use the output per capita to investigate if the level of development matters to explain the fatalities due to natural disasters across countries. Expenditure per capita measures the size of the municipal government and may exhibit ambiguous relationships with our measures of natural disaster impact. The authors argue that a large size of government may reflect an inefficiency of the public expending, which would lead to the large impact of natural disasters. However, a large size of government may

\footnotetext{
${ }^{13}$ Similar to the index of urban infrastructure, the index of water supply infrastructure is based on principal components and includes: the number of water pipeline systems serving the municipality, the total connections with water basin integration axes (so-called, Eixão das Águas), and the number of water dams. The index varies in the interval 0 to 100 as well.
} 
reflect the public investment that prevents the impact of natural disasters and helps the population to adapt to environmental adversities. Finally, tax revenue as a proportion of total revenue captures the capacity of the local government for coping with losses due to natural disasters. A high value of this variable indicates greater local effort and effectiveness in revenue generation that leads to greater financial resources for the provision of public goods and services (Yonson et al., 2017).

\subsection{Descriptive statistics}

The AVADAN provides information on the affected population (see Figure 4) and losses from disasters (see Figure 5). To capture the impact of natural disasters, two measures are assumed in the current study:

$$
A P_{i t}=\frac{\text { Affected Population }_{\text {it }}}{\text { Population }_{\text {it }-1}}
$$

and

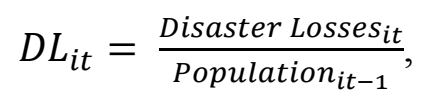

where $A P_{i t}$ is the proportion of the population affected by droughts and floods in municipality $i$ in the year $t$, and $D L_{i t}$ is the per capita losses due to natural disasters in municipality $i$ in the year $t$. Loayza et al. (2012) used the affected population normalized by population size to measure the impact of natural disasters on economic growth across countries, whereas Toya and Skidmore (2007) use economic damage relative to GDP. ${ }^{14}$ De Oliveira (2019) estimates the impact of per capita losses due to natural disasters on the economic growth rate of municipalities in the state of Ceará.

\footnotetext{
${ }^{14}$ Fatalities due to natural disasters have been used as the dependent variable in studies that investigate the association between natural disaster impact and economic development within and across countries (Toya and Skidmore, 2007; Yonson, 2017). However, this type of consequence of natural disasters is very infrequent in Ceará (CEPED, 2013), which led us to discard it as a measure of the impact of environmental shocks.
} 
In addition to reporting the descriptive statistics for the dependent variables and the measure of hazards, Table 1 displays the mean and standard deviation of the measures of exposure and vulnerability. Relative to exposure, on average, 20.3 thousand people are exposed to natural disasters in the state of Ceará, 12.9 thousand due to droughts and 7.4 due to floods.

\section{[INSERT TABLE 1 ABOUT HERE]}

The average score of the urban infrastructure is approximately 26.4 , which would be considered a low average score in the range from 0 to 100 . Similarly, water supply infrastructure shows an average score near 12.7 in the interval from 0 to 100 . In addition, the average population density is approximately 110 people per $\mathrm{km}^{2}$. Tax revenue shares only $3.4 \%$ of the total revenue, and public expenditure per capita is near R \$ 862 (or US\$ 619 PPP). The average GDP per capita is R $\$ 5,149$ (or US\$ 3,698 PPP). Table A1 of the appendix provides pairwise correlations among dependent variables and the set of covariates.

\section{Results}

\subsection{Baseline results}

Table 2 presents the baseline estimates for equation (4), which displays the estimated coefficients and marginal effects of the explanatory variables with respect to the expected value of the damages caused by natural disasters. Using the $3^{\text {rd }}$ quintile of the distribution of the deviations of annual precipitation regarding the historical mean as the reference category, the estimates show that only the $5^{\text {th }}$ quintile is positively and statistically significant. Municipalities with a deviation of annual precipitation in the $5^{\text {th }}$ quintile of the distribution exhibit, on average, a $0.19 \%$ increase in the expected proportion of the population affected by natural disasters, and expected disaster losses per capita increased by $0.52 \%$ in comparison with municipalities in the 
$3^{\text {rd }}$ quintile of the distribution. This result implies that the excess of rainfall is more likely to generate a larger disaster impact to municipalities than the lack of rainfall.

In terms of exposure to disasters, the results corroborate the literature (Peduzzi et al., 2009; Yonson et al. 2017) and show a positive relationship with the impact of natural disasters. Estimated marginal effects show that an increase of $1 \%$ in the exposed population to natural disasters leads to a variation in the expected proportion of the population affected by approximately $0.86 \%$, and $1.5 \%$ relative to the expected disaster losses per capita. This evidence is not surprising given that only 32 out of 184 municipalities (17.4\%) had a contingency or emergency plan for environmental disasters in 2011, 94 municipalities (51\%) had an urbanization plan, and 85 municipalities had a land use and occupation law (46.2\%) (IBGE, 2012). The lack of disaster risk reduction (DRR) measures may lead municipalities to face a large exposure level and, consequently, to experience large damages from natural disasters (Hallegatte et al., 2017). Therefore, policymakers should focus their efforts on the implementation of DRR measures to reduce the impacts of natural disasters.

\section{[INSERT TABLE 2 ABOUT HERE]}

In addition to the level of exposure, the level of vulnerability matters to predict the impact of natural disasters on municipalities as suggested by the joint significant statistics. For instance, an increase of $1 \%$ in the index of urban infrastructure would reduce the impact of natural disasters by $0.17 \%$ regarding the expected proportion of the population affected and $0.25 \%$ in terms of disaster losses per capita. Similar results are observed for the water supply infrastructure. An increase of $1 \%$ in the index would lead to a drop in the proportion of the population affected by $0.11 \%$ and nearly $0.18 \%$ relative to the disaster losses per capita. These results support the role played by the infrastructure in the adaptation for climate disaster 
(Hallegatte, 2009), which has been the main public policy of drought preparedness in Ceará (Gutiérrez et al., 2014).

In the early 1990s, the water scarcity caused by the unpredictable rainfall and frequent droughts induced public investment in the massive construction of reservoirs and related water infrastructure (Gutiérrez et al., 2014). In addition, the capacity of municipalities to provide large water supply infrastructure is very limited, and preparedness to environmental shocks is highly dependent on the public investment at the state and/or federal government level. ${ }^{15}$ This suggests that local governments are unlikely to individually influence the public investment to prevent natural disasters in Ceará.

Moreover, the impact of natural disasters is negatively associated with population density. An increase in population density by $1 \%$ would result in a reduction of $0.39 \%$ in the expected proportion of the population affected and $0.67 \%$ in the expected disaster losses per capita. This evidence may reflect the better (worse) capacity of response and adaptation of high (low) population density municipalities to natural disasters; however, population density has been widely treated by the literature as a risk factor for natural disasters (Birkmann, 2007). Cross (2001), for instance, argues that small cities and rural communities — which by definition have lower population densities - are more vulnerable to disasters since large cities and megacities often have considerable resources for dealing with hazards and disasters.

Table 2 also shows that the public finance of municipalities matters to predict the magnitude of the impact of natural disasters in the state of Ceará. Municipalities that increase the participation of their tax revenue relative to the total revenue by $1 \%$ would reduce the proportion of the population affected by $0.16 \%$ and the expected disaster losses per capita by $0.27 \%$. This evidence corroborates Toya and Skidmore (2007), who show that the government

\footnotetext{
${ }^{15}$ Between 2000 and 2011, public investment in water supply infrastructure was approximately US\$730 million, increasing human consumption to the Fortaleza Metropolitan Region from $6.6 \mathrm{~m} 3 / \mathrm{sec}$ in 2000 to $13.2 \mathrm{~m} 3 / \mathrm{sec}$ in 2011. This large water supply infrastructure (well-known as "Canal da Integração") benefited 3.6 million people from the urban areas and 300,000 people in the rural communities around the new reservoirs (Ceratti, 2013).
} 
size may reflect inefficiencies that lead to the large impact of natural disasters. However, an increase of $1 \%$ in the municipality expenditure per capita would result in an increase of $0.44 \%$ in the expected proportion of the population affected and $0.96 \%$ in the expected disaster losses per capita. Yonson et al. (2017) find that a variation of one percentage point in the proportion of tax revenue relative to total GDP would reduce the fatalities due to cyclones in the Philippines by $0.38 \%$.

This positive relationship between the impact of natural disasters and public spending may be driven by corruption at the municipality level. Evidence shows that large natural disasters in terms of damage increase public sector corruption in both developing and developed countries (Yamamura, 2014). A potential explanation is that unexpected resources to cope with disaster damages may be seen as an opportunity for mayors to exercise their rent-seeking behaviours (Nikolova and Marinov, 2017). In Brazil, federal transfers of constitutional and discretionary funds to municipalities lead to an increase in corruption (Assumpção, 2012; Brollo et al., 2013). Thus, our lagged public spending per capita can be capturing the inefficiencies of resource allocation caused by preceding corruption at the municipality level.

The results in Table 2 also show that the income of municipalities is negatively associated with the magnitude of the impact of natural disasters in the state of Ceará, which corroborates the specialized literature (Toya and Skidmore, 2007; Peduzzi et al., 2009; Yonson et al., 2017). An increase of $1 \%$ in the average income would reduce the expected proportion of the population affected by $0.52 \%$ and the expected disaster losses per capita by $0.64 \%$.

Our elasticities are in line with empirical evidence within and across countries. Toya and Skidmore show that elasticities for the number of fatalities due to natural disasters regarding GDP per capita are near -0.15 , and -0.12 relative to disaster losses as a fraction of the total GDP across countries. Yonson et al. (2017) estimate income elasticity near -1.13 regarding total fatalities due to cyclones in the Philippines normalized by population size. Peduzzi et al. (2009) 
find elasticities between the number of fatalities and GDP per capita across countries of -0.53 for cyclones, -4.54 for droughts, -0.70 in the case of floods. Therefore, the evidence in Table 2 shows that the level of economic development of a municipality is an important predictor for the impact of natural disasters.

\subsection{Nonlinearity in income effects}

Table 2 shows that the relationship between income and the impact of natural disasters across municipalities in the state of Ceará follows a linear form, similarly to within- and cross-country studies (Toya and Skidmore, 2007; Peduzzi et al., 2009; Yonson et al., 2017). However, Schumacher and Strobl (2011) predict that high hazard countries are likely to exhibit a Ushaped relationship between wealth and economic losses, while low hazard countries are likely to have an inversely U-shaped one.

Since Ceará is one of the most hazardous states in Brazil (CEPED, 2016), and belongs to one of the riskiest regions (Northeast Brazil) in the world due to the ongoing climate change (IPCC, 2012), it is important to investigate whether the relationship between natural disaster impact and income is nonlinear. To perform such analysis, the estimations in Table 2 are redone with the inclusion of the squared natural log of GDP per capita as an additional explanatory variable. The likelihood-ratio test (LR test) is computed as a way to compare the linear and nonlinear specification of income in the right-hand side of equation (4).

In Table 3, the LR test shows that the restricted and unrestricted models (i.e., models with the linear and nonlinear form of income) are not nested, which suggests that the quadratic form of income is the appropriate form to interpret its relationship with the natural disaster 
impact. The estimated parameters suggest a convex relationship between the measures of natural disaster impact and income with the low turning point at 9.3. ${ }^{16}$

\section{[INSERT TABLE 3 ABOUT HERE]}

This evidence is aligned with the predictions of Schumacher and Strobl (2011). The authors argue that high hazard countries are likely to undertake prevention expenditures even at very low levels of wealth, and experience decreasing losses with increasing wealth if the marginal benefits from prevention expenditure outweigh the costs. In this case, losses due to natural disasters may decrease with economic development. However, if the potential for prevention expenditure is limited, then the marginal benefits from further prevention expenditure may be decreasing. According to the authors, this effect should be more significant for high hazard countries than for low hazard ones, which may lead to increasing losses with higher levels of economic development.

This scenario appropriately fits what happens in the state of Ceará and, probably, with all the other states of the Northeast Region. As these municipalities reach higher levels of development, their vulnerability to natural disasters is reduced due to the increase of local investment in education, health, and urbanization, which are public services typically provided by the local government. However, local investment in access to water, sanitation, and housing is very limited and mostly depends on federal and state funds, as already mentioned. In this case, the limited investment capacity of the municipalities tends to be ineffective to fully prevent natural disasters when they attain higher levels of income. It seems to be shown in Figure 6, which suggests that an increase in the income level of rich municipalities does not

\footnotetext{
16 This sort of nonlinear relationship between the impact of natural disasters and income is also verified when we estimate the linear panel model with fixed effects of year and municipalities as shown by Table A2 of the appendix. However, the linear relationship between the impact of natural disasters and income is not significant.
} 
necessary lead to a large reduction in the likelihood of the impact of natural disasters, as would happen with poor municipalities.

\section{[INSERT FIGURE 6 ABOUT HERE]}

Therefore, it is important to investigate the source of such a nonlinear relationship, which is discussed in the next subsection.

\subsection{Differences due to the type of natural disaster}

The number of drought records is three times larger than the number of reported floods in Ceará between 2002 and 2011 (De Oliveira, 2019). Thus, it is relevant to know whether the shape of the relationship between the impact of natural disasters and income is driven by the type of environmental shock. Table 4 displays the estimated coefficients when we separately model the impact of droughts and floods.

\section{[INSERT TABLE 4 ABOUT HERE]}

In general, the results from Table 4 support the evidence in Tables 2 and 3. However, some heterogeneous coefficients arise when we separately model the impact of droughts and floods. First, we notice that the excess of rainfall is positively associated with the impact of floods, but the lack of rainfall does not significantly predict the impact of droughts. Particularly, the absence of the predictive power of the natural hazard measures regarding the impact of droughts can be explained by the inclusion of the vulnerability measures, since hazardous events tend to be more harmful in vulnerable areas (Sawada and Takasaki, 2017). Moreover, measures of the exposed population remain positively associated with the corresponding types 
of natural disasters, and the measures of vulnerability exhibit similar estimates, as observed in Tables 2 and 3.

An important result that emerges from Table 4 is that the relationship between the impact of droughts and income is a nonlinear, as verified in Table 3 and supported by the LR test. The low turning point of the natural log of the lagged GDP per capita is at 9.2, either modelling the impact in terms of the population affected or economic damages. In contrast, the impact of floods is linearly decreasing with municipality income.

This result may reflect the low capacity of the municipalities in reducing the socioeconomic risks associated with droughts, which is directly conditioned to the lack of integration of DRR measures (e.g., contingency or emergency plan for disasters, urbanization plan, land use, and occupation law) into their development plans and policies (Hay and Mimura, 2010; Hallegatte et al., 2017). In 2011, for instance, 112 out of 184 municipalities had not even started the elaboration of Agenda 21 at the local level (IBGE, 2012). ${ }^{17}$ Consequently, municipalities may focus on economic activities that are highly vulnerable to environmental shocks. For instance, $62 \%$ of all water resources in Ceará are allocated to irrigation, whereas manufacturing is responsible for only $13.5 \%$. The urban and rural demand respond with $18.7 \%$ and $2.6 \%$, respectively (CGEE, 2012). The lack of DRR measures and their low integration with the development plans of the municipalities may lead to the inefficient use of natural resources and higher exposure and impact of natural disasters as they become wealthier.

The elaboration of a contingency or emergency plan for environmental disasters is essential in the context of the majority of these municipalities that face a high risk of droughts. Although the Ceará state has modern resource management for large bodies of water (Gutierréz

\footnotetext{
17 The Brazilian Agenda 21 is a participatory planning instrument for the sustainable development of the country, the result of extensive consultation with the Brazilian population. It was coordinated by the Sustainable Development Policy Commission and Agenda 21; built on the guidelines of Global Agenda 21; and finally delivered to society in 2002. For further details, access the link: https://www.mma.gov.br/responsabilidadesocioambiental/agenda- 21 .
} 
et al., 2014), municipalities need to implement efficient policies of water usage to promote sustainable development and to be more resilient to this type of natural disaster.

\subsection{Accounting for spatial dependence}

The literature has shown evidence of the spatial dependence among the local economies in Brazil (Resende, 2011; Özyurt and Daumal, 2013; Resende et al., 2015; Lima and Silveira Neto, 2016). In our study, the spatial dependence may manifest itself in terms of spatial spillover of explanatory variables (Lima and Barbosa, 2017), especially regarding measures of vulnerability to natural disasters. For instance, large public investment associated with the water supply infrastructure usually benefits a group of municipalities (e.g., building large water reservoirs or water pipelines), which may reduce their vulnerability to droughts and, at the same time, create an economic spillover among them. Another example is the regional hierarchy of the public health services, in which municipalities are organized into agglomerations (or "health" regions) that facilitate resource allocation to meet local demand.

To capture the spatial spillover, we re-estimate the specifications of Table 3 including spatial lagged explanatory variables like the SLX specification (Vega and Elhorst, 2015). However, the LR test and the joint significance test suggest that the spatial spillover is not captured by the spatial lagged covariates (see Table A3 of the appendix). However, spatial dependence associated with the dependent variable may be latent in model (4). Figures 4 and 5 show that damages from natural disasters are not uniformly distributed over the territory, in which some municipalities are more affected than others. Thus, we re-estimate the specification of Table 3 including the corresponding spatial lagged dependent variable like the SAR model (Elhorst, 2014). In Table 5, the Moran MI and Geary GC suggest the existence of a positive spatial dependency of the measure of the impact of natural disasters, which is confirmed by the estimated coefficients of the spatial lagged dependent variable. 
Table 5 shows similar results to those presented in Table 3 . We observe that not only the excess but also the lack of rainfall is significant and positively associated with the magnitude of the impact of the disasters (see Figure 7). The estimated coefficients for the exposure measure and for the measures of vulnerabilities remain with the same signal and similar magnitude, including the estimated nonlinear shape of income, which shows a low turning point of approximately 9.0 .

\section{[INSERT TABLE 5 ABOUT HERE]}

\section{[INSERT FIGURE 7 ABOUT HERE]}

We also estimate the direct and indirect (spillover) effects of the covariates (see Table A4 of the appendix). The direct effects are larger than the indirect effects of neighbouring municipalities. In summary, the results from the panel Tobit model are robust to spatial dependence on the impact of natural disasters.

\section{Conclusion}

In this study, we show that the provision of better urban and water supply infrastructure, the improvement in the tax collection and the efficiency of the public expenditures of municipalities are associated with the smaller impact of natural disasters, measured by the affected population and total losses caused by droughts and floods in the Ceará state.

However, the predicted relationship between the impact of environmental shocks (i.e., droughts) and income is convex, suggesting that an increase in the income level of rich municipalities does not necessarily lead to a large reduction in the expected impact of natural disasters. This result is obtained at the subnational level, contributing to the literature that has mainly provided evidence at the country level (Kahn, 2005; Toya and Skidmore, 2007; Peduzzi 
et al., 2009; Schumacher and Strobl, 2011). Another important contribution is related to evidence that this nonlinear relationship depends on the type of natural disaster, which has not been documented by the specialized literature yet (Raschky, 2008; Schumacher and Strobl, 2011).

Although the majority of the municipalities of Ceará lie within the semi-arid region of Brazil, there is a lack of implementation of DRR measures (e.g., contingency or emergency plan for disasters, urban plan, land use, and occupation law) that can lead them to experience a larger exposure and larger impact of natural disasters as they become wealthier. Moreover, the absence of DRR measures may also induce a low integration of prevention and adaptation policies into the development plans of municipalities (e.g., low adoption of Agenda 21). Consequently, municipalities may stimulate economic activities that are vulnerable to environmental shocks. Thus, policymakers should focus their efforts on increasing the implementation of DRR measures and integrating them into the development policies of municipalities to ensure sustainable development at the local level. 


\section{FIGURES}

Figure 1: Map of Ceará state, Northeast, Brazil

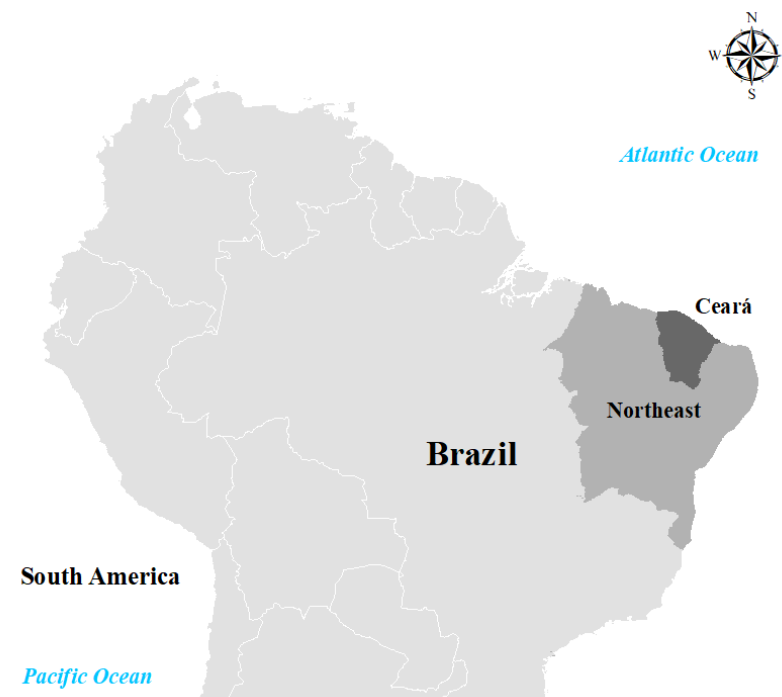

Source: Elaborated by authors.

Figure 2: Normalized deviation of annual precipitation of municipalities regarding their historical average

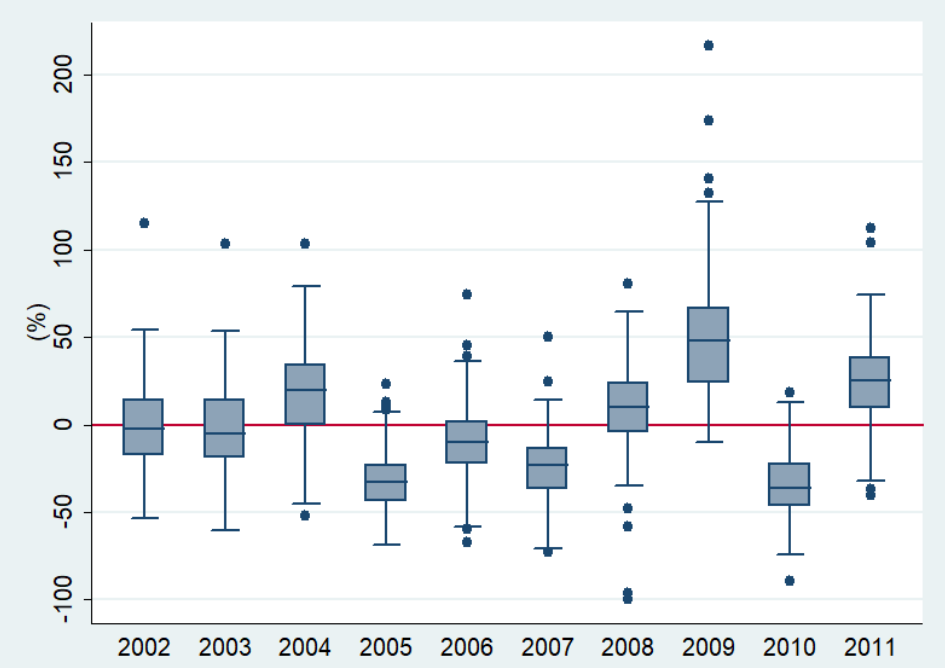

Source: Fundação Cearense de Meteorologia e Recursos Hídricos FUNCEME. 
Figure 3: Spatial distribution of damage reports related to natural disasters in Ceará between 2002 and 2011

(a) Damage reports related to droughts

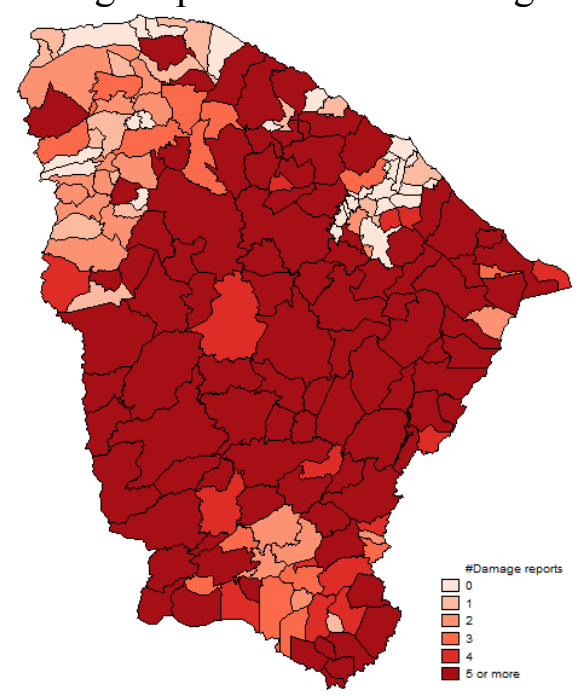

Source: Elaborated by authors. (b) Damage reports related to floods

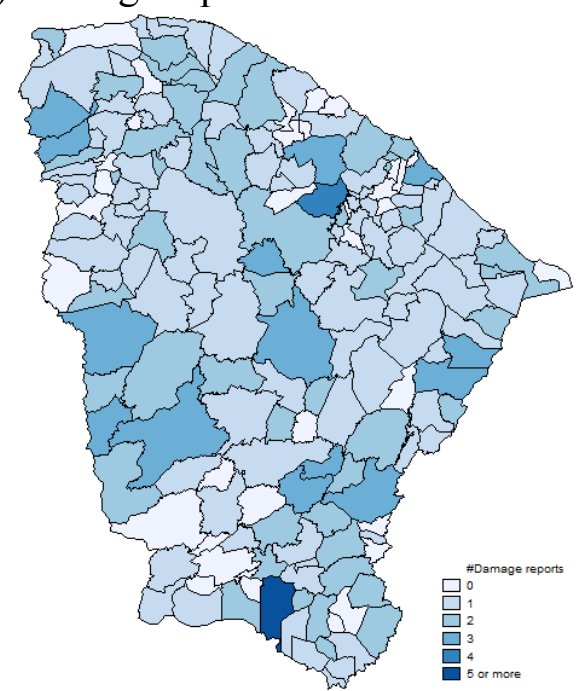

Figure 4: Spatial distribution of population affected by natural disasters in Ceará between 2002 and 2011

(a) Population affected by droughts

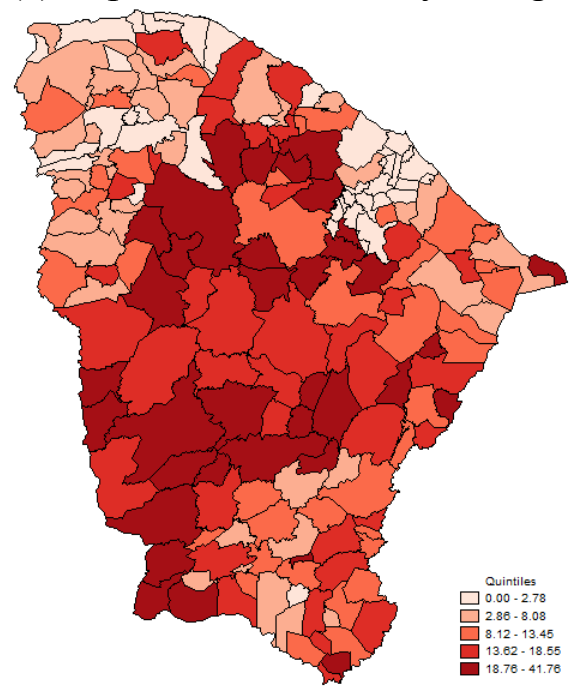

Source: Elaborated by authors. (b) Population affected by floods

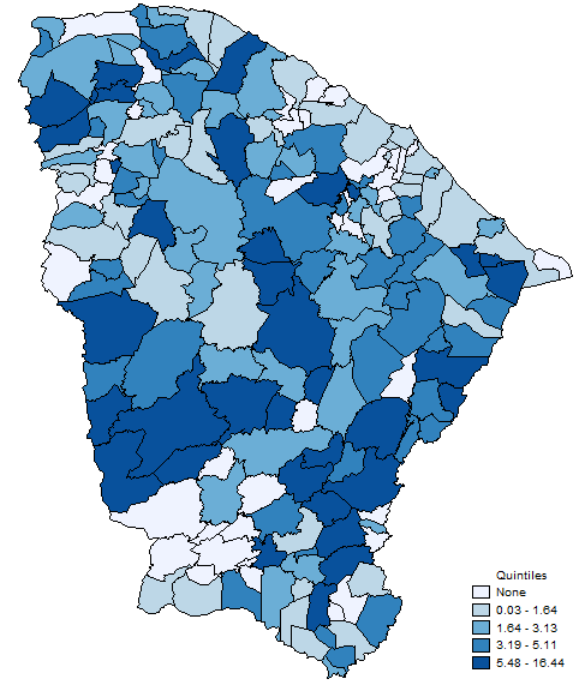


Figure 5: Spatial distribution of per capita losses due to natural disasters in Ceará between 2002 and 2011

(a) Per capita losses due to droughts

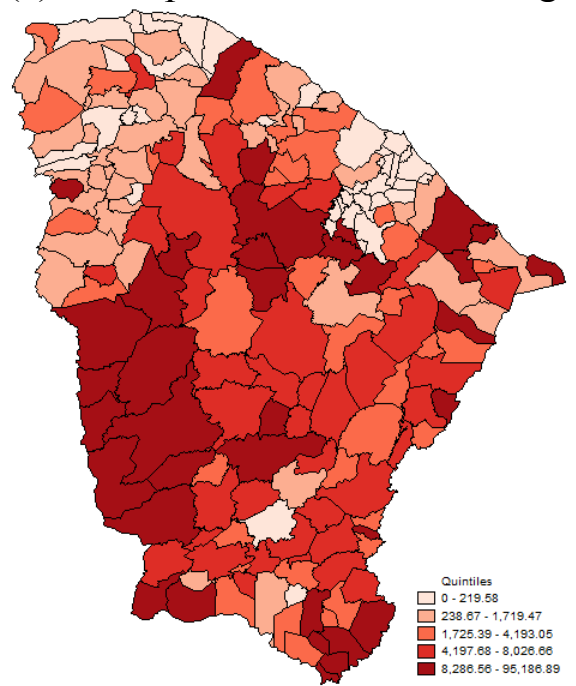

(b) Per capita losses due to floods

Source: Elaborated by authors.

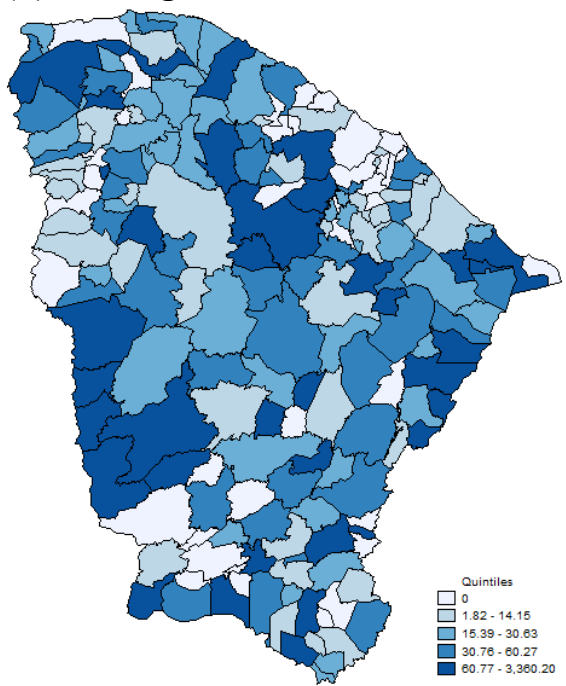

Figure 6: Predictive margins for the likelihood of the impact of natural disasters by municipality income level

(a) Dependent variable: $\ln$ (Affected Pop./ Pop.)

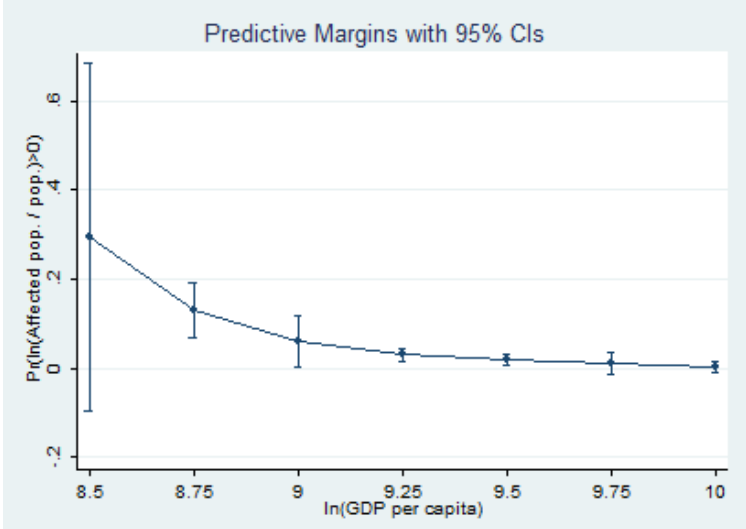

(b) Dependent variable: $\ln$ (Disaster Losses/Pop.)

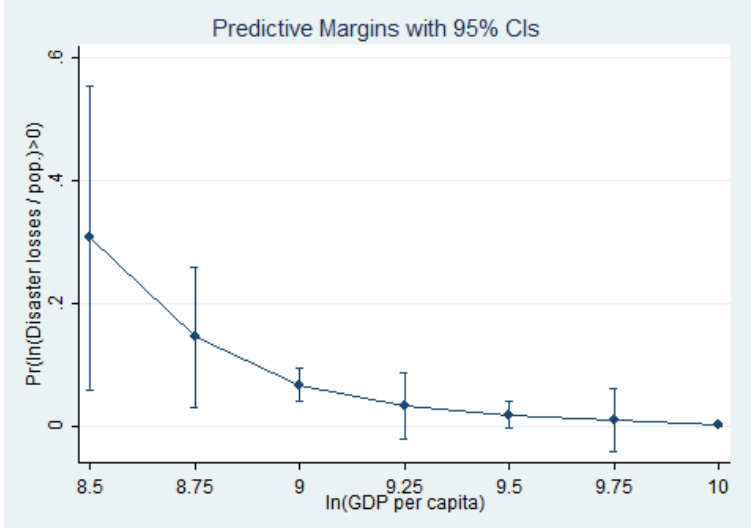

Source: Elaborated by authors. 
Figure 7: Estimated coefficients of hazard controls from Tobit and from Spatial Autoregressive Tobit

(a) Tobit (Table 3): $\ln$ (Affected Pop./ Pop.)

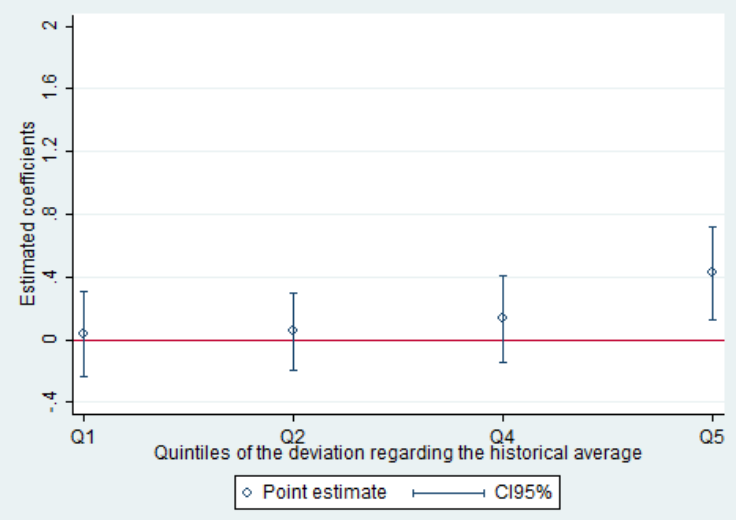

(c) SAR Tobit (Table 5): $\ln$ (Affected Pop./ Pop.)

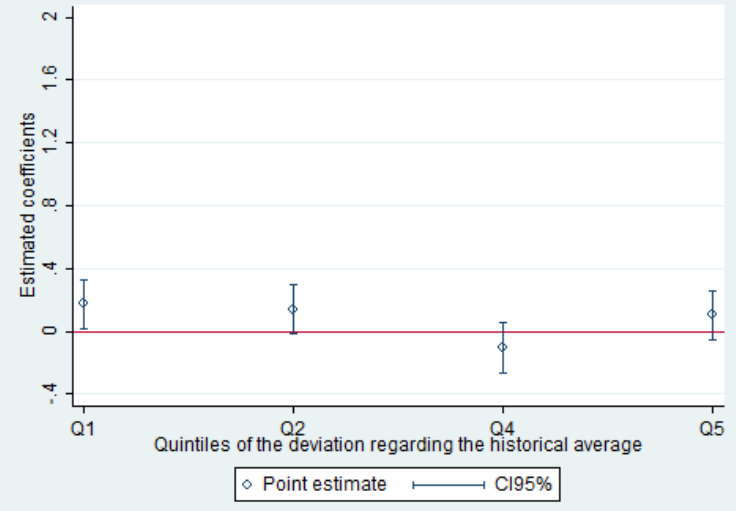

Source: Elaborated by authors. (b) Tobit (Table 3): $\ln ($ Disaster Losses/Pop.)

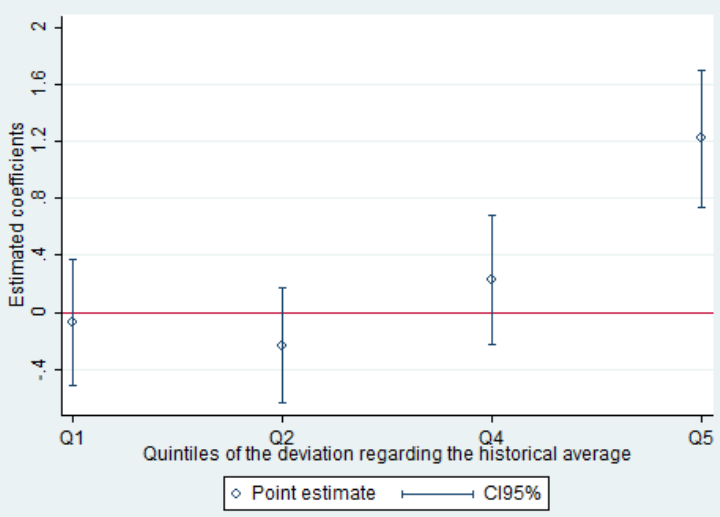

(d) SAR Tobit (Table 5): $\ln$ (Disaster Losses/Pop.)

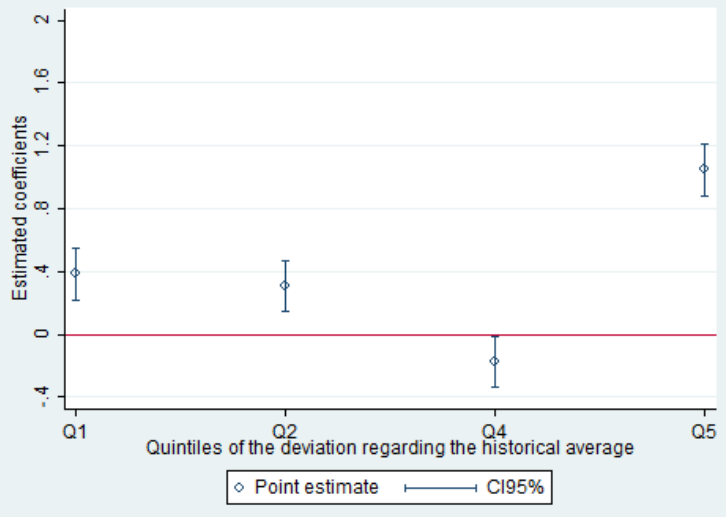




\section{TABLES}

Table 1: Descriptive statistics

\begin{tabular}{|c|c|c|c|c|}
\hline & \multicolumn{2}{|c|}{ Absolute values } & \multicolumn{2}{|c|}{ Natural log } \\
\hline & Mean & SD & Mean & SD \\
\hline \multicolumn{5}{|l|}{ Dependent variables } \\
\hline Affected population relative to population (\%) & 8.017 & 11.922 & 1.177 & 1.459 \\
\hline Total losses per capita $(\mathrm{R} \$)$ & 119.016 & 846.143 & 1.857 & 2.410 \\
\hline \multicolumn{5}{|l|}{ Hazard controls } \\
\hline Deviation of annual precipitation from the historical mean $(\%)$ & -0.524 & 34.431 & - & - \\
\hline \multicolumn{5}{|l|}{ Exposure } \\
\hline Exposed population $\mathrm{x}$ disaster event & 20,259 & 83,603 & 9.243 & 1.048 \\
\hline Droughts & 12,896 & 31,899 & 9.041 & 0.942 \\
\hline Floods & 7,363 & 77,543 & 8.734 & 0.657 \\
\hline \multicolumn{5}{|l|}{ Vulnerability controls } \\
\hline Urban infrastructure index & 26.42 & 15.95 & 3.082 & 0.623 \\
\hline Water supply infrastructure & 12.71 & 15.67 & 1.820 & 1.351 \\
\hline Population density (pop./ $\mathrm{km}^{2}$ ) & 110 & 575.93 & 3.723 & 0.939 \\
\hline Tax revenue relative to total revenue $(\%)$ & 3.41 & 2.62 & 1.080 & 0.497 \\
\hline Municipal expenditure per capita (R\$) & 862.26 & 275.70 & 6.673 & 0.315 \\
\hline GDP per capita $(\mathrm{R} \$)$ & $5,148.76$ & $3,128.97$ & 8.431 & 0.374 \\
\hline Observations & & & & 1,656 \\
\hline
\end{tabular}

Note: Own elaboration. 
Table 2: Baseline results from panel Tobit model with random effects

\begin{tabular}{|c|c|c|c|c|}
\hline & \multicolumn{2}{|c|}{ In(Affected Pop./ Pop.) } & \multicolumn{2}{|c|}{$\ln ($ Disaster Losses/Pop.) } \\
\hline & Coefficients & $\begin{array}{c}\text { Marginal } \\
\text { Effects }\end{array}$ & Coefficients & $\begin{array}{c}\text { Marginal } \\
\text { Effects }\end{array}$ \\
\hline \multicolumn{5}{|l|}{ Hazard controls } \\
\hline $1^{\text {st }}$ quintile of the deviation of annual precipitation & $\begin{array}{c}0.024 \\
(0.139)\end{array}$ & $\begin{array}{c}0.010 \\
(0.059)\end{array}$ & $\begin{array}{l}-0.074 \\
(0.228)\end{array}$ & $\begin{array}{l}-0.031 \\
(0.095)\end{array}$ \\
\hline $2^{\text {nd }}$ quintile of the deviation of annual precipitation & $\begin{array}{c}0.045 \\
(0.128)\end{array}$ & $\begin{array}{c}0.019 \\
(0.054)\end{array}$ & $\begin{array}{c}-0.234 \\
(0.208)\end{array}$ & $\begin{array}{l}-0.098 \\
(0.088)\end{array}$ \\
\hline $4^{\text {th }}$ quintile of the deviation of annual precipitation & $\begin{array}{c}0.135 \\
(0.142)\end{array}$ & $\begin{array}{c}0.057 \\
(0.060)\end{array}$ & $\begin{array}{c}0.229 \\
(0.231)\end{array}$ & $\begin{array}{c}0.096 \\
(0.098)\end{array}$ \\
\hline $5^{\text {th }}$ quintile of the deviation of annual precipitation & $\begin{array}{c}0.438 * * * \\
(0.152)\end{array}$ & $\begin{array}{c}0.186 * * * \\
(0.068)\end{array}$ & $\begin{array}{c}1.237 * * * \\
(0.246)\end{array}$ & $\begin{array}{c}0.518 * * * \\
(0.122)\end{array}$ \\
\hline \multicolumn{5}{|l|}{ Exposure control } \\
\hline $\ln$ (Population $\mathrm{x}$ reported natural disaster) & $\begin{array}{c}2.037 * * * \\
(0.070)\end{array}$ & $\begin{array}{c}0.864 * * * \\
(0.108)\end{array}$ & $\begin{array}{c}3.501 * * * \\
(0.123)\end{array}$ & $\begin{array}{c}1.466^{* * *} \\
(0.187)\end{array}$ \\
\hline \multicolumn{5}{|l|}{ Lagged vulnerability controls } \\
\hline $\ln ($ Urban infrastructure $)$ & $\begin{array}{c}-0.406^{* * *} \\
(0.122)\end{array}$ & $\begin{array}{c}-0.172 * * * \\
(0.056)\end{array}$ & $\begin{array}{c}-0.596 * * * \\
(0.201)\end{array}$ & $\begin{array}{c}-0.250 * * * \\
(0.090)\end{array}$ \\
\hline $\ln ($ Water supply infrastructure) & $\begin{array}{c}-0.262 * * * \\
(0.056)\end{array}$ & $\begin{array}{c}-0.111 * * * \\
(0.027)\end{array}$ & $\begin{array}{c}-0.418 * * * \\
(0.095)\end{array}$ & $\begin{array}{c}-0.175 * * * \\
(0.045)\end{array}$ \\
\hline $\ln$ (Population density) & $\begin{array}{c}-0.926^{* * *} \\
(0.105)\end{array}$ & $\begin{array}{c}-0.392 * * * \\
(0.065)\end{array}$ & $\begin{array}{c}-1.607 * * * \\
(0.184)\end{array}$ & $\begin{array}{c}-0.673 * * * \\
(0.113)\end{array}$ \\
\hline $\ln ($ Tax revenue relative to total revenue) & $\begin{array}{c}-0.372 * * * \\
(0.113)\end{array}$ & $\begin{array}{c}-0.158 * * * \\
(0.052)\end{array}$ & $\begin{array}{c}-0.646 * * * \\
(0.184)\end{array}$ & $\begin{array}{c}-0.271 * * * \\
(0.084)\end{array}$ \\
\hline $\ln$ (Municipal expenditure per capita) & $\begin{array}{c}1.037 * * * \\
(0.245)\end{array}$ & $\begin{array}{c}0.440 * * * \\
(0.117)\end{array}$ & $\begin{array}{c}2.288 * * * \\
(0.398)\end{array}$ & $\begin{array}{c}0.958 * * * \\
(0.206)\end{array}$ \\
\hline $\ln ($ GDP per capita $)$ & $\begin{array}{c}-1.231 * * * \\
(0.248) \\
\end{array}$ & $\begin{array}{c}-0.522 * * * \\
(0.123)\end{array}$ & $\begin{array}{c}-1.522 * * * \\
(0.415) \\
\end{array}$ & $\begin{array}{c}-0.637 * * * \\
(0.191) \\
\end{array}$ \\
\hline \multicolumn{5}{|l|}{ Joint significant test (Chi-square) } \\
\hline Hazard controls & $9.177 *$ & & $36.076 * * *$ & \\
\hline Lagged vulnerability controls & $258.330 * * *$ & & $233.053 * * *$ & \\
\hline \multicolumn{5}{|l|}{ RE Tobit versus Pooled Tobit } \\
\hline LR test (Chi-square) & $116.26 * * *$ & & $156.15 * * *$ & \\
\hline Likelihood ratio & $2062.375 * * *$ & & $2013.498 * * *$ & \\
\hline Loglikelihood & -1327.835 & & -1783.772 & \\
\hline Observations & 1,656 & & 1,656 & \\
\hline
\end{tabular}


Table 3: Results from panel Tobit model with random effects, accounting for nonlinearities in income effects

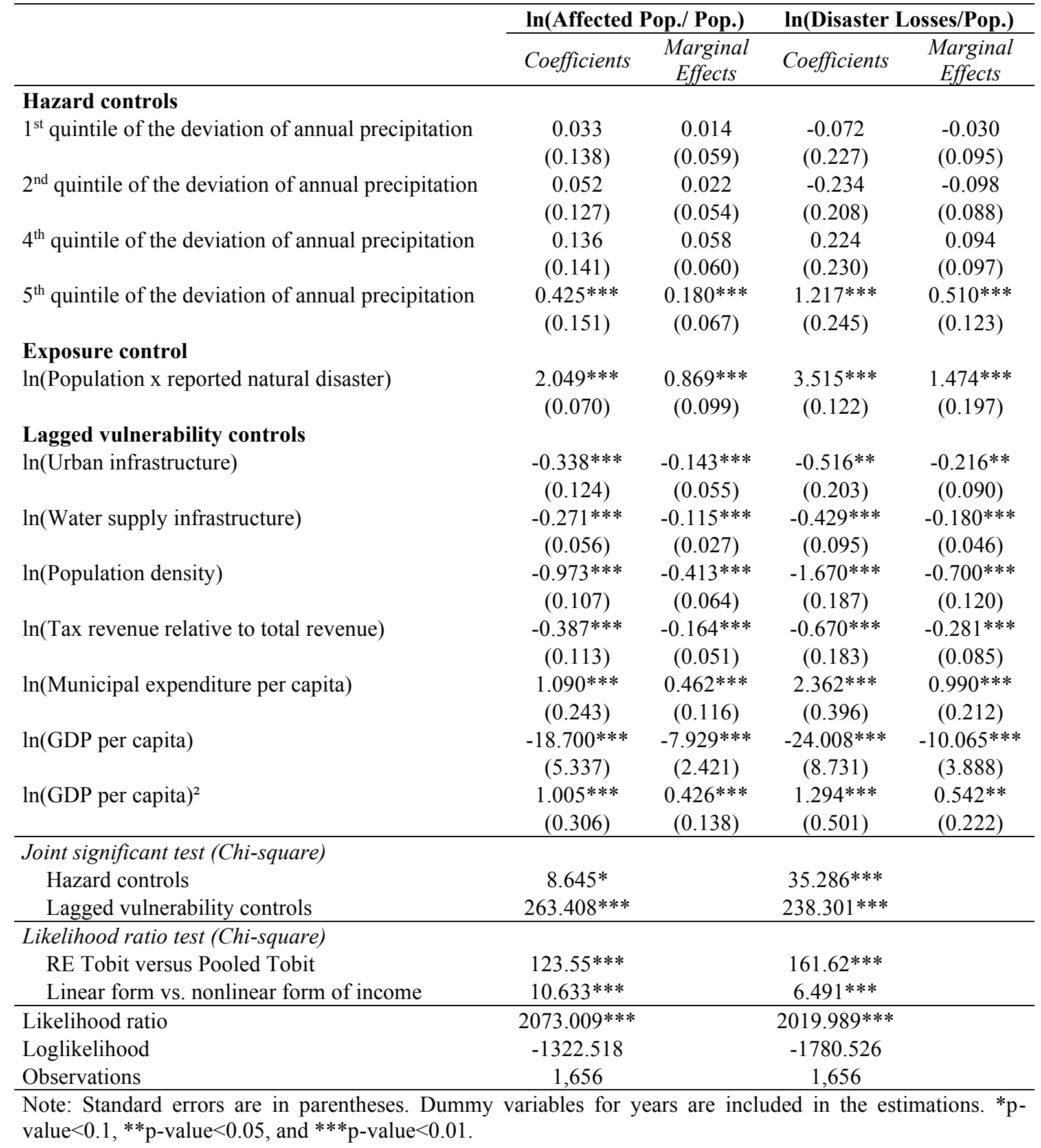


Table 4: Results from panel Tobit model for type of natural disaster

\begin{tabular}{|c|c|c|c|c|}
\hline & \multicolumn{2}{|c|}{ In(Affected Pop./ Pop.) } & \multicolumn{2}{|c|}{ In(Disaster Losses/Pop.) } \\
\hline & Droughts & Floods & Droughts & Floods \\
\hline \multicolumn{5}{|l|}{ Hazard controls } \\
\hline \multirow[t]{2}{*}{$1^{\text {st }}$ quintile of the deviation of annual precipitation } & -0.035 & -0.129 & -0.140 & -0.040 \\
\hline & $(0.181)$ & $(0.577)$ & $(0.394)$ & $(0.871)$ \\
\hline \multirow[t]{2}{*}{$2^{\text {nd }}$ quintile of the deviation of annual precipitation } & -0.041 & 0.410 & -0.443 & 0.608 \\
\hline & $(0.167)$ & $(0.503)$ & $(0.359)$ & $(0.769)$ \\
\hline \multirow[t]{2}{*}{$4^{\text {th }}$ quintile of the deviation of annual precipitation } & -0.119 & $0.829 * *$ & -0.135 & $1.084 * *$ \\
\hline & $(0.197)$ & $(0.340)$ & $(0.429)$ & $(0.533)$ \\
\hline \multirow[t]{2}{*}{$5^{\text {th }}$ quintile of the deviation of annual precipitation } & -0.327 & $1.246 * * *$ & -0.484 & $2.222 * * *$ \\
\hline & $(0.248)$ & $(0.323)$ & $(0.537)$ & $(0.500)$ \\
\hline \multicolumn{5}{|l|}{ Exposure controls } \\
\hline \multirow[t]{2}{*}{$\ln$ (Population $x$ reported droughts) } & $2.398 * * *$ & & $6.085 * * *$ & \\
\hline & $(0.092)$ & & $(0.221)$ & \\
\hline \multirow[t]{2}{*}{$\ln$ (Population $\mathrm{x}$ reported floods) } & & $3.050 * * *$ & & $5.009 * * *$ \\
\hline & & $(0.182)$ & & $(0.286)$ \\
\hline \multicolumn{5}{|l|}{ Lagged vulnerability controls } \\
\hline \multirow[t]{2}{*}{$\ln ($ Urban infrastructure $)$} & $-0.351 * *$ & $-0.473 * *$ & -0.464 & $-1.009 * * *$ \\
\hline & $(0.161)$ & $(0.200)$ & $(0.366)$ & $(0.311)$ \\
\hline \multirow[t]{2}{*}{$\ln ($ Water supply infrastructure) } & $-0.335 * * *$ & $-0.334 * * *$ & $-0.743 * * *$ & $-0.560 * * *$ \\
\hline & $(0.071)$ & $(0.091)$ & $(0.169)$ & $(0.148)$ \\
\hline \multirow[t]{2}{*}{$\ln$ (Population density) } & $-1.240 * * *$ & $-1.089 * * *$ & $-2.828 * * *$ & $-1.857 * * *$ \\
\hline & $(0.143)$ & $(0.166)$ & $(0.354)$ & $(0.273)$ \\
\hline \multirow[t]{2}{*}{$\ln ($ Tax revenue relative to total revenue) } & -0.232 & $-1.282 * * *$ & -0.492 & $-2.079 * * *$ \\
\hline & $(0.152)$ & $(0.244)$ & $(0.337)$ & $(0.380)$ \\
\hline \multirow[t]{2}{*}{$\ln$ (Municipal expenditure per capita) } & $1.291 * * *$ & $1.988 * * *$ & $3.939 * * *$ & $2.497 * * *$ \\
\hline & $(0.330)$ & $(0.514)$ & $(0.738)$ & $(0.801)$ \\
\hline \multirow[t]{2}{*}{$\ln ($ GDP per capita) } & $-21.247 * * *$ & $-1.729 * * *$ & $-48.864 * * *$ & $-1.508 * *$ \\
\hline & $(7.899)$ & $(0.466)$ & $(17.414)$ & $(0.734)$ \\
\hline \multirow[t]{2}{*}{$\ln (\text { GDP per capita })^{2}$} & $1.150^{* *}$ & & $2.653 * * *$ & \\
\hline & $(0.456)$ & & $(1.005)$ & \\
\hline \multicolumn{5}{|l|}{ Joint significant test (Chi-square) } \\
\hline Hazard controls & 1.747 & $19.788 * * *$ & 2.284 & $28.698 * * *$ \\
\hline Lagged vulnerability controls & $195.770 * * *$ & $128.881 * * *$ & $171.217 * * *$ & $121.582 * * *$ \\
\hline \multicolumn{5}{|l|}{ Likelihood ratio test (Chi-square) } \\
\hline RE Tobit versus Pooled Tobit & $76.10 * * *$ & $10.62 * * *$ & $128.41 * * *$ & $16.18^{* * *}$ \\
\hline Linear form vs. nonlinear form of income & $6.037 * *$ & 0.001 & $6.416^{* *}$ & 0.131 \\
\hline Likelihood ratio & $1972.031 * * *$ & $1159.322 * * *$ & $1975.932 * * *$ & $1210.472 * * *$ \\
\hline Loglikelihood & -1078.137 & -489.990 & -1670.873 & -598.049 \\
\hline Observations & 1,656 & 1,656 & 1,656 & 1,656 \\
\hline
\end{tabular}

Note: Standard errors are in parentheses. Dummy variables for years are included in the estimations. *pvalue $<0.1, * * \mathrm{p}$-value $<0.05$, and $* * * \mathrm{p}$-value $<0.01$. 
Table 5: Results from panel Tobit model accounting for spatial dependence of the dependent variable

\begin{tabular}{|c|c|c|}
\hline & In(Affected Pop./ Pop.) & In(Disaster Losses/Pop.) \\
\hline \multicolumn{3}{|l|}{ Hazard controls } \\
\hline \multirow[t]{2}{*}{$1^{\text {st }}$ quintile of the deviation of annual precipitation } & $0.176^{* *}$ & $0.384 * * *$ \\
\hline & $(0.079)$ & $(0.085)$ \\
\hline \multirow[t]{2}{*}{$2^{\text {nd }}$ quintile of the deviation of annual precipitation } & $0.139^{*}$ & $0.312 * * *$ \\
\hline & $(0.080)$ & $(0.082)$ \\
\hline \multirow[t]{2}{*}{$4^{\text {th }}$ quintile of the deviation of annual precipitation } & -0.103 & $-0.176^{* *}$ \\
\hline & $(0.080)$ & $(0.081)$ \\
\hline \multirow[t]{2}{*}{$5^{\text {th }}$ quintile of the deviation of annual precipitation } & 0.105 & $1.048 * * *$ \\
\hline & $(0.079)$ & $(0.083)$ \\
\hline \multicolumn{3}{|l|}{ Exposure controls } \\
\hline \multirow{2}{*}{$\ln ($ Population $\mathrm{x}$ reported natural disaster) } & $1.065 * * *$ & $1.876^{* * *}$ \\
\hline & $(0.034)$ & $(0.041)$ \\
\hline \multicolumn{3}{|l|}{ Lagged vulnerability controls } \\
\hline \multirow[t]{2}{*}{$\ln ($ Urban infrastructure $)$} & $-0.246 * * *$ & $-0.850 * * *$ \\
\hline & $(0.053)$ & $(0.058)$ \\
\hline \multirow[t]{2}{*}{$\ln ($ Water supply infrastructure) } & $-0.062 * * *$ & $-0.123 * * *$ \\
\hline & $(0.020)$ & $(0.022)$ \\
\hline \multirow[t]{2}{*}{$\ln$ (Population density) } & $-0.236 * * *$ & $-0.347 * * *$ \\
\hline & $(0.033)$ & $(0.034)$ \\
\hline \multirow[t]{2}{*}{$\ln ($ Tax revenue relative to total revenue) } & $-0.107 * *$ & $-0.635 * * *$ \\
\hline & $(0.054)$ & $(0.053)$ \\
\hline \multirow[t]{2}{*}{$\ln$ (Municipal expenditure per capita) } & $0.585 * * *$ & $0.739 * * *$ \\
\hline & $(0.086)$ & $(0.090)$ \\
\hline \multirow[t]{2}{*}{$\ln ($ GDP per capita) } & $-10.059 * * *$ & $-9.835 * * *$ \\
\hline & $(1.980)$ & $(2.298)$ \\
\hline \multirow[t]{2}{*}{$\ln (\text { GDP per capita })^{2}$} & $0.556^{* * *}$ & $0.566^{* * *}$ \\
\hline & $(0.113)$ & $(0.132)$ \\
\hline \multirow[t]{2}{*}{ Spatial lagged dependent variable } & $0.057 * * *$ & $0.057 * * *$ \\
\hline & $(0.005)$ & $(0.004)$ \\
\hline \multicolumn{3}{|l|}{ Joint significant test (Chi-square) } \\
\hline Hazard controls & $16.019 * * *$ & $250.772 * * *$ \\
\hline Lagged vulnerability controls & $410.834 * * *$ & $1835.705 * * *$ \\
\hline \multicolumn{3}{|l|}{ LR test of specification } \\
\hline $\mathrm{H}_{0}$ : SAR vs. OLS & $132.866 * * *$ & $253.733 * * *$ \\
\hline \multicolumn{3}{|l|}{ Spatial dependence } \\
\hline Moran MI & $0.2842 * * *$ & $0.1656^{* * *}$ \\
\hline Geary GC & $0.7497 * * *$ & $0.8536^{* * *}$ \\
\hline Akaike & 0.8022 & 2.3506 \\
\hline Schwarz & 0.8370 & 2.4526 \\
\hline Loglikelihood & -2352.656 & -4255.004 \\
\hline Observations & 1,656 & 1,656 \\
\hline
\end{tabular}

Note: Standard errors are in parentheses. Dummy variables for years are included in the estimations. These estimations use the Queen contiguity weight matrix. *p-value $<0.1, * *$ p-value $<0.05$, and ***p-value $<0.01$. 


\section{References}

Assumpção A (2012) Estimating the effect of discretionary spending on corruption: evidence from Brazilian municipalities. [Available at] SSRN: https://ssrn.com/abstract=2675142

Birkmann J (2007) Risk and vulnerability indicators at different scales: applicability, usefulness and policy implications. Environmental Hazards 7(1), 20-31

Brollo F, Nannicini T, Peroti R, Tabellini G. (2013) The political resource curse. American Economic Review 103(5): 1759-1796

Cardona OD (2011) Disaster risk and vulnerability: notions and measurement of human and environmental insecurity. In: Brauch HG, Spring UO, Mesjasz C, Grin J, Kameri-Mbote P, Chourou B, Dunay P, Birkmann J (eds) Coping with Global Environmental Change, Disasters and Security - Threats, Challenges, Vulnerabilities and Risks. Springer Verlag, Berlin, Germany

Cavallo E, Noy I (2011) Natural disasters and the economy - a survey. International Review of Environmental and Resource Economics 5: 63-102

CEPED (2013) Atlas brasileiro de desastres naturais - 1991 a 2012. [Availabel at] https://s2id.mi.gov.br/paginas/atlas/

CEPED (2016) Relatório dos danos materiais e prejuízos decorrentes de desastres naturais no Brasil: 1995 - 2014. [Available at] http://www.ceped.ufsc.br/relatorio-de-danos-materiais-eprejuizos-decorrentes-de-desastres-naturais-no-brasil-1995-2014/

CGEE (2012) A questão da água no Nordeste. Centro de Gestão e Estudos Estratégicos, Agência Nacional das Águas, Brasília - DF. [Available at] http://livroaberto.ibict.br/bitstream/1/669/4/A\%20quest $\%$ C3\%A3o\%20da $\% 20 \% \mathrm{C} 3 \% \mathrm{~A} 1$ gua $\%$ 20no\%20Nordeste.pdf

Ceratti M (2013) Better water supply for Northeast Brazil. [Available at] http://www.worldbank.org/en/results/2013/04/03/Brazil-Northeast-Ceara-water-resources-managementproject.

Cross JA (2001) Megacities and small towns: different perspectives on hazard vulnerability. Environmental Hazards 3 (2): 63-80

De Oliveira, VH (2019) Natural disasters and economic growth in Northeast Brazil: evidence from municipal economies of the Ceará state. Environment and Development Economics 24(3): $271-293$

Greene W (2004) fixed effects and bias due to the incidental parameters problem in the Tobit model. Econometric Reviews 23(2): 125-147

Gutiérrez AP, Engle NL, Nys E, Molejón C, Martins ES (2014) Drought preparedness in Brazil, Weather and Climate Extremes 3: 95-106 
Hallegatte S (2009) Strategies to adapt to an uncertain climate change. Global Environmental Change 19(2): 240-247

Hallegatte S, Vogt-Schilb A, Bangalore M, Rozenberg, J (2017) Unbreakable: building the resilience of the poor in the face of natural disasters. The World Bank Group. Washington, DC.

Hay J, Mimura N (2010) The changing nature of extreme weather and climate events: risks to sustainable development. Geomatics, Natural Hazards and Risk 1(1): 3-18

Hummell BML, Cutter SL, Emrich CT (2016) Social vulnerability to natural hazards in Brazil. Int J Disaster Risk Sci 7(2): 111-122

IBGE (2012) Pesquisa de Informações Básicas Municipais - 2012. [Available at] https://www.ibge.gov.br/estatisticas/multidominio/meio-ambiente/10586-pesquisa-deinformacoes-basicas-municipais.html?edicao $=18195 \& \mathrm{t}=$ downloads

IPCC (2012) Managing the Risks of Extreme Events and Disasters to Advance Climate Change Adaptation. A Special Report of Working Groups I and II of the Intergovernmental Panel on Climate Change. Cambridge, UK: Cambridge University Press

Kahn ME (2005) The death toll from natural disasters: the role of income, geography, and institutions. Review of Economics and Statistics 87(2): 271-284

Kellenberg DK, Mobarak AM (2008) Does rising income increase or decrease damage risk from natural disasters? Journal of Urban Economics 63(3): 788-802

Lima RCA, Barbosa AV (2018) Natural disasters, economic growth and spatial spillovers: evidence from flash floods in Brazil. Papers in Regional Science. Doi:10.1111/pirs.12380

Lima, RC, Silveira Neto R (2016) Physical and human capital and Brazilian regional growth: a spatial econometric approach for the period 1970-2010. Regional Studies 50(10): 1688-1701

Loayza N, Olaberría E, Rigolini J, Christiaensen L (2012) Natural disasters and growth: going beyond the averages. World Development 40(7): 1317-1336

Marengo, JA, Alves LM, Alvala RCS, Cunha AP, Brito S, Moraes OLL (2017) Climatic characteristics of the 2010-2016 drought in the semiarid Northeast Brazil region. Annals of the Brazilian Academy of Sciences 90 (2 Suppl. 1). Doi: 10.1590/0001-3765201720170206

MIN (2007), Manual para decretação de estado de emergência ou estado de calamidade pública. [Available at] http://www.mi.gov.br/c/document_library/get_file?uuid=aac1713a-727f-4275be98 6e06abc775cc\&groupId $=10157$

Nikolova E, Marinov N (2017) Do public fund windfalls increase corruption? Evidence from a natural disaster. Comparative Political Studie. Doi: 10.1177/0010414016679109

Okuyama Y, Sahin S (2009) Impact estimation of disasters: a global aggregate for 1960 to 2007. World Bank Policy Research Working Papers no 4963. [Available at] http://documents.worldbank.org/curated/en/787121468340170531/pdf/WPS4963.pdf 
Özyurt S, Daumal M (2013) Trade openness and regional income spillovers in Brazil: a spatial econometric approach. Papers in Regional Science 92(1): 197-215

PBMC (2015) Sumário Executivo. In: Volume 1: Base Científica das Mudanças Climáticas. Contribuição do Grupo de Trabalho 1 ao Primeiro Relatório de Avaliação Nacional do Painel Brasileiro de Mudanças Climáticas, 2013-2015

Peduzzi P, Dao H, Herold C, Mouton F (2009) Assessing global exposure and vulnerability towards natural hazards: the disaster risk index. Natural Hazards and Earth System Sciences 9(4): 1149-1159

Rasch RJ (2016). Assessing urban vulnerability to flood hazard in Brazilian municipalities. Environment and Urbanization 28(1): 145-168.

Raschky PA (2008). Institutions and the losses from natural hazards. Natural Hazards and Earth System Sciences 8: 627-634

Resende G (2011) Multiple dimensions of regional economic growth: the Brazilian case, 19912000. Papers in Regional Science 90(3): 629-662.

Resende GM, De Carvalho AXY, Sakowski PAM, Cravo, TA (2015) Evaluating multiple spatial dimensions of economic growth in Brazil using spatial panel data models. The Annals of Regional Science 56: 1-31

Schumacher I, Strobl E (2011) Economic development and losses due to natural disasters: the role of hazard exposure. Ecological Economics 72: 97-105

Sawada Y, Takasaki Y (2017) Natural disasters, poverty, and development: an introduction. World Development 94:2-15

Toya H, Skidmore M (2007) Economic development and the impacts of natural disasters. Economics Letters 94: 20-25

UNDP (2004) Reducing Disaster Risk: A Challenge for Development (A Global Report). UNDP, New York, NY

UNDRO (1980) Natural Disasters and Vulnerability Analysis (Report of Experts Group Meeting of 9-12 July 1979). UNDRO, Geneva, Switzerland

UNISDR (2004) Living With Risk. United Nations International Strategy for Disaster Reduction, Geneva, Switzerland

UNISDR (2009) Terminology on Disaster Risk Reduction. United Nations International Strategy for Disaster Reduction, Geneva, Switzerland

UNISDR (2011) Global Assessment Report on Disaster Risk Reduction: Revealing Risk, Redefining Development. United Nations International Strategy for Disaster Reduction, Geneva

UNISDR (2017) Economic Losses, Poverty, \& Disasters 1998-2017. United Nations International Strategy for Disaster Reduction, Geneva 
Vega SH, Elhorst JP (2015) The SLX model. Journal of Regional Science 55(3): 339-363

Wisner B, Blaikie P, Cannon T, Davis I (2004) At risk: natural hazards, people's vulnerability, and disasters ( $2^{\text {nd }}$ ed.). London: Routledge

Yamamura E (2014) Impact of natural disaster on public sector corruption. Public Choice 61(34): $385-405$

Yonson R, Noy I, Gaillard JC (2017) The measurement of disaster risk: an example from tropical cyclones in the Philippines. Rev. Dev. Econ. 22(2): 736-765

Zhou Y, Liu YS, Wu WX, Li N (2015) Integrated risk assessment of multi-hazards in China. Nat Hazards 78: 257-280 


\section{Appendix}

Table A1: Pairwise correlations

\begin{tabular}{|c|c|c|c|c|c|c|c|c|c|c|c|c|c|c|c|c|}
\hline & $\ln \mathbf{A P}$ & $\operatorname{lnDL}$ & Q1 & Q2 & Q3 & Q4 & Q5 & $\ln E$ & $\ln E d$ & $\operatorname{lnEf}$ & $\ln I$ & $\ln H$ & $\ln P D$ & $\ln T R$ & $\ln G E$ & $\operatorname{lnGDP}$ \\
\hline $\ln \mathrm{AP}$ & 1 & & & & & & & & & & & & & & & \\
\hline $\operatorname{lnDL}$ & $0.85 * * *$ & 1 & & & & & & & & & & & & & & \\
\hline Q1 & $0.13 * * *$ & $0.09 *$ & 1 & & & & & & & & & & & & & \\
\hline Q2 & $0.08 * * *$ & 0.01 & $-0.25 * * *$ & 1 & & & & & & & & & & & & \\
\hline Q3 & $-0.08 * * *$ & $-0.11 * * *$ & $-0.25 * * *$ & $-0.25 * * *$ & 1 & & & & & & & & & & & \\
\hline Q4 & $-0.12 * * *$ & $-0.12 * * *$ & $-0.25 * * *$ & $-0.25 * * *$ & $-0.25 * * *$ & 1 & & & & & & & & & & \\
\hline Q5 & $-0.02 * * *$ & $0.12 * * *$ & $-0.25 * * *$ & $-0.25 * * *$ & $-0.25 * * *$ & $-0.25 * * *$ & 1 & & & & & & & & & \\
\hline $\ln E$ & $0.69 * * *$ & $0.67 * * *$ & $0.11 * * *$ & $0.07 * * *$ & $-0.05 * *$ & $-0.10 * * *$ & -0.03 & 1 & & & & & & & & \\
\hline $\operatorname{lnEd}$ & $0.61 * * *$ & $0.45^{* * *}$ & $0.21 * * *$ & $0.16^{* * *}$ & 0.00 & $-0.13 * * *$ & $-0.24 * * *$ & $0.80 * * *$ & 1 & & & & & & & \\
\hline $\operatorname{lnEf}$ & $0.26 * * *$ & $0.45^{* * *}$ & $-0.13 * * *$ & $-0.13 * * *$ & $-0.07 * * *$ & $0.05 * * *$ & $0.28 * * *$ & $0.50 * * *$ & $-0.09 * * *$ & 1 & & & & & & \\
\hline $\ln I$ & $-0.07 * * *$ & $-0.06 * *$ & $0.06 * *$ & -0.02 & 0.01 & -0.01 & -0.04 & $0.19 * * *$ & $0.13 * * *$ & $0.12 * * *$ & 1 & & & & & \\
\hline $\ln H$ & $0.12 * * *$ & $0.13 * * *$ & 0.00 & 0.00 & 0.00 & 0.02 & -0.02 & $0.24 * * *$ & $0.20 * * *$ & $0.10 * * *$ & $0.06^{* *}$ & 1 & & & & \\
\hline $\ln P D$ & $-0.29 * * *$ & $-0.25 * * *$ & 0.01 & -0.02 & 0.00 & 0.00 & 0.01 & $-0.11 * * *$ & $-0.17 * * *$ & $0.04 *$ & $0.39 * * *$ & $-0.26 * * *$ & 1 & & & \\
\hline $\ln T R$ & $-0.07 * * *$ & $-0.07 * * *$ & 0.01 & -0.02 & 0.02 & -0.01 & 0.00 & $0.10 * * *$ & $0.06^{* *}$ & $0.08 * * *$ & $0.35 * * *$ & 0.02 & $0.26^{* * *}$ & 1 & & \\
\hline $\ln G E$ & $-0.17 * * *$ & $-0.11 * * *$ & $-0.10 * * *$ & $-0.11 * * *$ & -0.04 & $0.04 *$ & $0.20 * * *$ & $-0.31 * * *$ & $-0.33 * * *$ & -0.03 & $-0.05^{* *}$ & $-0.13 * * *$ & -0.02 & 0.01 & 1 & \\
\hline InGDP & $-0.16^{* * *}$ & $-0.10 * * *$ & 0.01 & $-0.07 * * *$ & -0.02 & -0.01 & $0.09 * * *$ & 0.03 & $-0.05^{*}$ & $0.12^{* * *}$ & $0.57 * * *$ & -0.03 & $0.52 * * *$ & $0.45^{* * *}$ & $0.25 * * *$ & 1 \\
\hline
\end{tabular}

Note: The list of variables includes: $\ln \mathrm{AP}=$ natural $\log$ of the proportion of affected population relative to total population size; $\operatorname{lnDL}=$ natural log of total losses per capita; $\ln \mathrm{E}=$ natural $\log$ of exposed population to natural disasters; $\operatorname{lnEd}=$ natural $\log$ of exposed population to droughts; $\operatorname{lnEf}=$ natural log of exposed population floods; $\mathrm{Q} 1=\mathrm{I}\left(1^{\text {st }}\right.$ quintile of the distribution of the deviation of annual precipitation $)$, $Q 2=I\left(2^{\text {nd }}\right.$ quintile of the distribution of the deviation of annual precipitation $)$; $33=\mathrm{I}\left(3^{\text {rd }}\right.$ quintile of the distribution of the deviation of annual precipitation); $\mathrm{Q} 4=\mathrm{I}\left(4^{\text {th }}\right.$ quintile of the distribution of the deviation of annual precipitation $)$; $\mathrm{Q} 5=\mathrm{I}\left(5^{\text {th }}\right.$ quintile of the distribution of the deviation of annual precipitation); $\ln \mathrm{I}=$ natural $\log$ of the index of urban infrastructure; $\ln \mathrm{H}=$ natural $\log$ of the index of water supply infrastructure; $\ln \mathrm{PD}=$ natural $\log$ of population density; $\ln \mathrm{TR}=$ natural $\log$ of the proportion of tax revenue relative to total revenue; $\operatorname{lnGE}=$ natural $\log$ of the municipal government expenditures per capita; $\operatorname{lnGDP}=$ natural $\log$ of municipal GDP per capita.

$*_{\mathrm{p}}$-value $<0.1, * * \mathrm{p}$-value $<0.05$, and $* * * \mathrm{p}$-value $<0.01$ 
Table A2: Results from linear panel model with time and municipality fixed effects.

\begin{tabular}{|c|c|c|c|c|}
\hline & \multicolumn{2}{|c|}{ Ln(Affected Pop./ Pop.) } & \multicolumn{2}{|c|}{ In(Disaster Losses/Pop.) } \\
\hline & (1) & $(2)$ & (3) & (4) \\
\hline \multicolumn{5}{|l|}{ Hazard controls } \\
\hline \multirow[t]{2}{*}{$1^{\text {st }}$ quintile of the deviation of annual precipitation } & 0.028 & 0.037 & -0.056 & -0.043 \\
\hline & $(0.077)$ & $(0.076)$ & $(0.140)$ & $(0.139)$ \\
\hline \multirow[t]{2}{*}{$2^{\text {nd }}$ quintile of the deviation of annual precipitation } & 0.032 & 0.027 & -0.107 & -0.114 \\
\hline & $(0.072)$ & $(0.072)$ & $(0.124)$ & $(0.124)$ \\
\hline \multirow[t]{2}{*}{$4^{\text {th }}$ quintile of the deviation of annual precipitation } & 0.118 & 0.107 & 0.165 & 0.151 \\
\hline & $(0.075)$ & $(0.075)$ & $(0.127)$ & $(0.126)$ \\
\hline \multirow[t]{2}{*}{$5^{\text {th }}$ quintile of the deviation of annual precipitation } & $0.211 * *$ & $0.190 * *$ & $0.740 * * *$ & $0.711 * * *$ \\
\hline & $(0.089)$ & $(0.088)$ & $(0.155)$ & $(0.152)$ \\
\hline \multicolumn{5}{|l|}{ Exposure control } \\
\hline \multirow[t]{2}{*}{$\ln$ (Population $\mathrm{x}$ reported natural disaster) } & $0.934 * * *$ & $0.939 * * *$ & $1.521 * * *$ & $1.528 * * *$ \\
\hline & $(0.069)$ & $(0.067)$ & $(0.112)$ & $(0.110)$ \\
\hline \multicolumn{5}{|l|}{ Lagged vulnerability controls } \\
\hline \multirow[t]{2}{*}{$\ln ($ Urban infrastructure $)$} & 0.057 & 0.084 & -0.052 & -0.013 \\
\hline & $(0.151)$ & $(0.140)$ & $(0.192)$ & $(0.179)$ \\
\hline \multirow[t]{2}{*}{$\ln$ (Water supply infrastructure) } & 0.042 & 0.025 & 0.081 & 0.057 \\
\hline & $(0.108)$ & $(0.106)$ & $(0.149)$ & $(0.146)$ \\
\hline \multirow[t]{2}{*}{$\ln$ (Population density) } & -0.048 & -0.757 & 0.004 & -0.992 \\
\hline & $(0.471)$ & $(0.489)$ & $(0.781)$ & $(0.780)$ \\
\hline \multirow[t]{2}{*}{$\ln ($ Tax revenue relative to total revenue) } & -0.102 & $-0.129 * *$ & $-0.204 *$ & $-0.242 * *$ \\
\hline & $(0.062)$ & $(0.060)$ & $(0.116)$ & $(0.114)$ \\
\hline \multirow[t]{2}{*}{$\ln$ (Municipal expenditure per capita) } & 0.090 & 0.204 & 0.065 & 0.225 \\
\hline & $(0.183)$ & $(0.182)$ & $(0.248)$ & $(0.246)$ \\
\hline \multirow[t]{2}{*}{$\ln ($ GDP per capita) } & -0.397 & $-17.647 * * *$ & -0.589 & $-24.829 * * *$ \\
\hline & $(0.262)$ & $(3.901)$ & $(0.460)$ & $(5.208)$ \\
\hline \multirow[t]{2}{*}{$\ln (\text { GDP per capita })^{2}$} & & $0.973 * * *$ & & $1.368 * * *$ \\
\hline & & $(0.221)$ & & $(0.290)$ \\
\hline \multicolumn{5}{|l|}{ Joint significant test (Chi-square) } \\
\hline Hazard controls & 1.452 & 1.200 & $8.545 * * *$ & $8.279 * * *$ \\
\hline Vulnerability controls & 1.076 & $4.361 * * *$ & 0.928 & $3.642 * * *$ \\
\hline Global significance F-test & 20.061 & 29.338 & 26.474 & 33.209 \\
\hline $\mathrm{R}^{2}$ & 0.731 & 0.736 & 0.701 & 0.705 \\
\hline Adjusted $\mathrm{R}^{2}$ & 0.694 & 0.699 & 0.659 & 0.663 \\
\hline Observations & 1,656 & 1,656 & 1,656 & 1,656 \\
\hline
\end{tabular}

Note: Clustered standard errors at municipality are in parentheses. $*$ p-value $<0.1,{ }^{*}$ p-value $<0.05$, and $* * * p$-value $<0.01$. 
Table A3: Results from panel Tobit model accounting for spatial lagged covariates

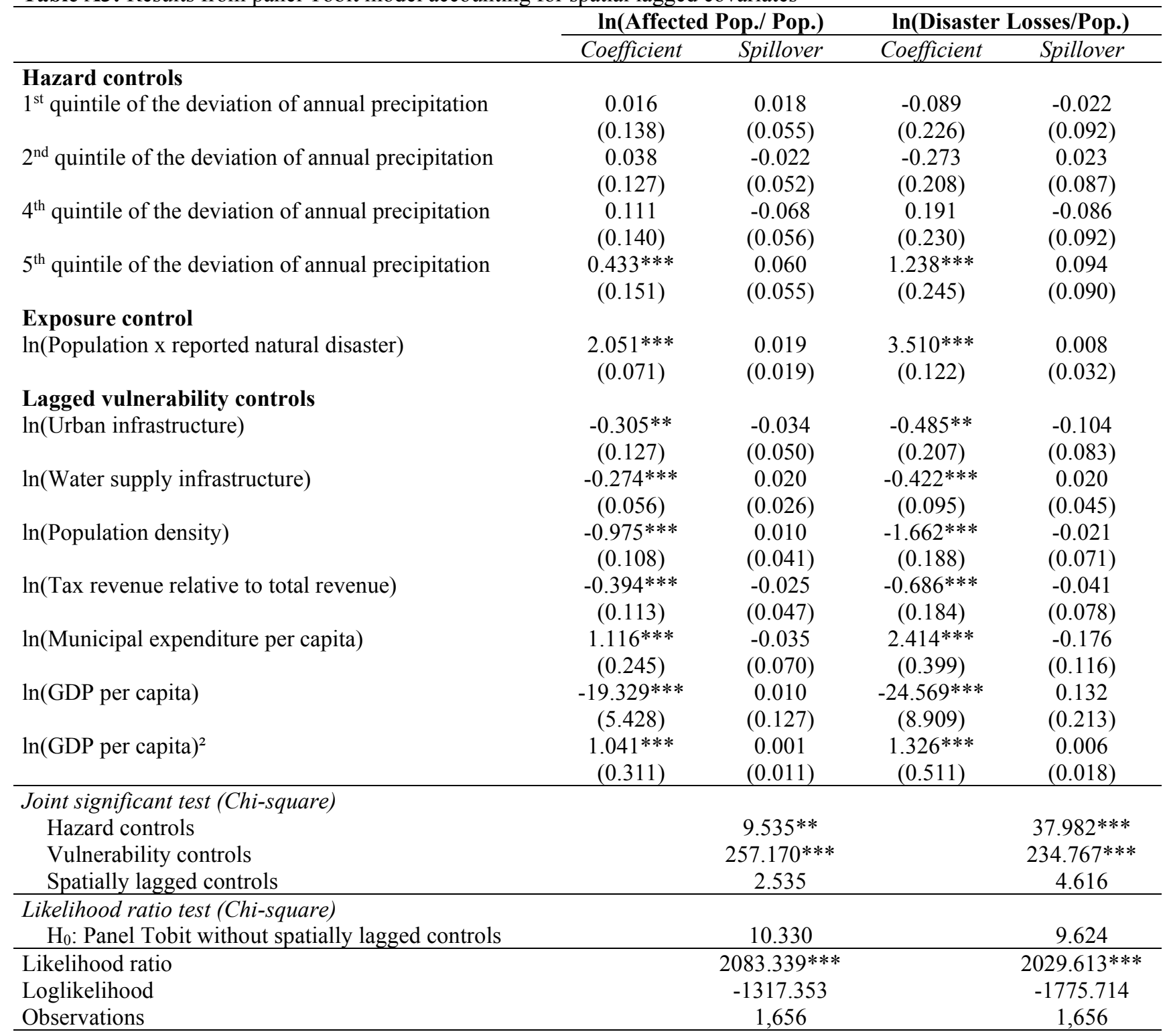

Note: Standard errors are in parentheses. Dummy variables for years are included in the estimations. The vector of spatial lagged covariates was generated using the Queen contiguity weight matrix. ${ }^{*} \mathrm{p}$-value $<0.1,{ }^{* *} \mathrm{p}$-value $<0.05$, and $* * * p$ value $<0.01$. 
Table A4: Total, direct and indirect coefficients from panel Tobit model with spatial lagged dependent variable

\begin{tabular}{|c|c|c|c|c|c|c|}
\hline & \multicolumn{3}{|c|}{ In(Affected Pop./ Pop.) } & \multicolumn{3}{|c|}{ In(Disaster Losses/Pop.) } \\
\hline & Total & Direct & Indirect & Total & Direct & Indirect \\
\hline \multicolumn{7}{|l|}{ Hazard controls } \\
\hline $1^{\text {st }}$ quintile of the deviation of annual precipitation & 0.175 & 0.123 & 0.052 & 0.382 & 0.268 & 0.114 \\
\hline $2^{\text {nd }}$ quintile of the deviation of annual precipitation & 0.138 & 0.097 & 0.041 & 0.310 & 0.218 & 0.093 \\
\hline $4^{\text {th }}$ quintile of the deviation of annual precipitation & -0.103 & -0.072 & -0.031 & -0.175 & -0.123 & -0.052 \\
\hline $5^{\text {th }}$ quintile of the deviation of annual precipitation & 0.104 & 0.073 & 0.031 & 1.042 & 0.731 & 0.311 \\
\hline \multicolumn{7}{|l|}{ Exposure control } \\
\hline $\ln$ (Population $\mathrm{x}$ reported natural disaster) & 1.059 & 0.744 & 0.314 & 1.865 & 1.309 & 0.556 \\
\hline \multicolumn{7}{|l|}{ Lagged vulnerability controls } \\
\hline $\ln ($ Urban infrastructure) & -0.245 & -0.172 & -0.073 & -0.845 & -0.593 & -0.252 \\
\hline $\ln$ (Water supply infrastructure) & -0.062 & -0.043 & -0.018 & -0.123 & -0.086 & -0.037 \\
\hline $\ln$ (Population density) & -0.235 & -0.165 & -0.070 & -0.345 & -0.242 & -0.103 \\
\hline $\ln ($ Tax revenue relative to total revenue) & -0.106 & -0.075 & -0.032 & -0.631 & -0.443 & -0.188 \\
\hline $\ln ($ Municipal expenditure per capita) & 0.582 & 0.409 & 0.173 & 0.735 & 0.515 & 0.219 \\
\hline $\ln ($ GDP per capita $)$ & -10.000 & -7.031 & -2.968 & -9.777 & -6.860 & -2.917 \\
\hline $\ln (\text { GDP per capita })^{2}$ & 0.553 & 0.389 & 0.164 & 0.562 & 0.395 & 0.168 \\
\hline Observations & 1,656 & 1,656 & 1,656 & 1,656 & 1,656 & 1,656 \\
\hline
\end{tabular}

Note: The estimated coefficients use the estimated parameters from Table 5. 